\title{
Chapter 3 \\ Emigration from Latvia: A Brief History and Driving Forces in the Twenty-First Century
}

\author{
Mihails Hazans
}

\subsection{Introduction}

In recent years, Latvia has experienced waves of intense emigration, establishing it as one of the worst-affected among EU/EFTA member states. This is true with respect to both post-crisis emigration rates of working-age nationals (Fries-Tersch et al. 2017, Fig. 7-8) and the total (as of 2015) mobility rates of working-age nationals (Fries-Tersch et al. 2017, Fig. 9). ${ }^{1}$ Remarkably, this finding is robust with respect to data source: the emigration rates come from migration statistics, while mobility rates are based on EU Labour Force Survey (LFS) data.

Emigration from Latvia is an interesting subject not only because of its intensity. In many other high emigration countries, population is a redundant factor, but this is not the case in Latvia. Since the beginning of the twenty-first century, loss of population due to emigration has been reinforced by negative natural change in all three Baltic countries, as well as in Bulgaria and Romania (Fig. 3.1). In 17 years (2000-2016), Latvia and Lithuania have lost the largest population shares (about $20 \%$ ) among EU countries. Moreover, Latvia and Lithuania are among the top three countries (after Bulgaria) with the largest negative natural population changes during this period.

This contrasts with positive demographic developments in the main destination countries of Baltic migrants - the UK, Ireland, the Nordic countries, and Germany. Only Germany features negative natural change, but it is not as big as in Latvia and has been more than compensated by positive net migration (Fig. 3.1).

\footnotetext{
${ }^{1}$ Latvia ranks second in both cases - after Lithuania in the former and after Romania (before Portugal and Lithuania) in the latter.
}

\section{Hazans $(\bowtie)$}

Faculty of Business, Management and Economics, University of Latvia, Rīga, Latvia e-mail: mihails.hazans@lu.lv 


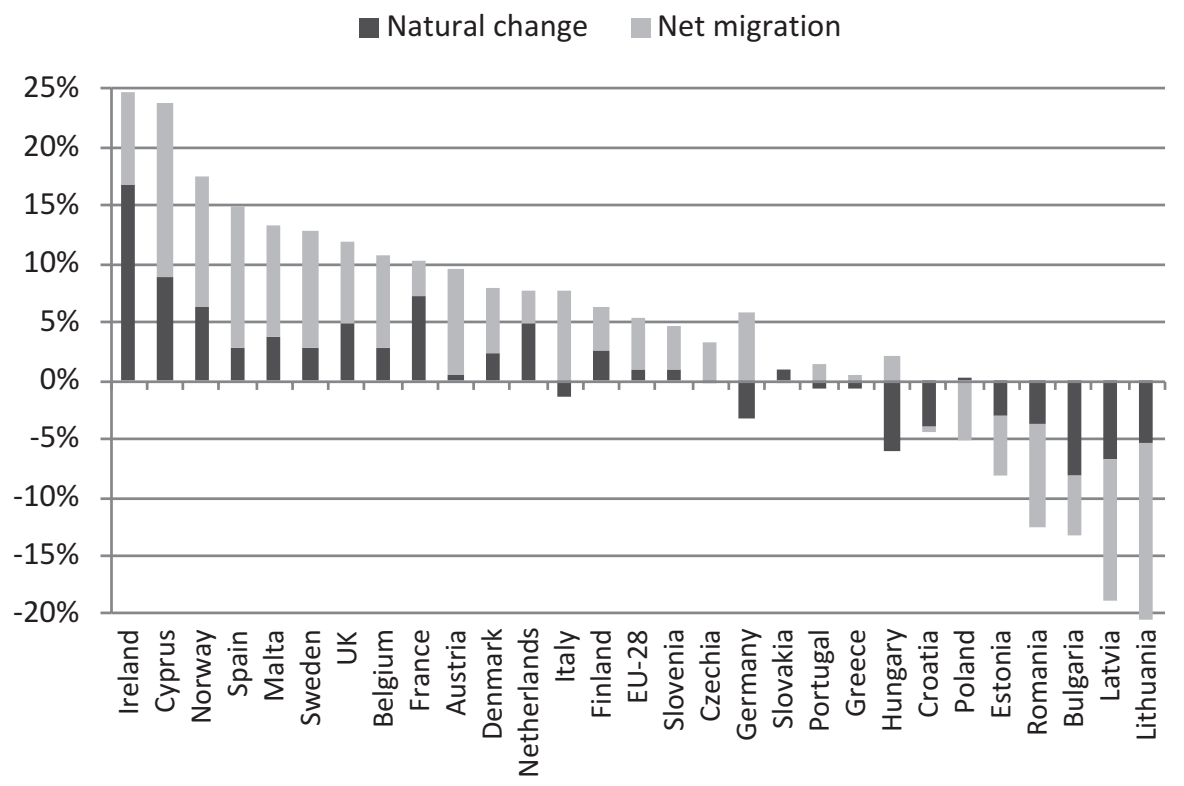

Fig. 3.1 Natural change of population and net migration, 2000-2016. EU28+Norway. (Source: Calculation with Eurostat data. For the Baltic countries data and Poland, the migration statistics of destination countries have been used to correct national net migration data (see Hazans 2013, 2015a, 2016a, 2017a), thus increasing estimates of net migration outflows by $0.7-1.9$ points for the Baltic countries and by 4.6 points for Poland)

Natural decrease of Latvia's population has been driven both by low total fertility rate (TFR) ${ }^{2}$ and high mortality (especially among men).

Latvia's population is ageing steadily. Between 2000 and 2015 the percentage share of children and teenagers shrank, while the shares of those aged 40-64 and especially $65+$ grew. The working-age population in Latvia is shrinking faster than in any OECD country except Japan (OECD 2016). In that period 2000-2015, the old age dependency ratio (OADR, 65+/15-64) in Latvia was higher and growing faster than in the main destination countries of Latvian migrants (except for Germany). According to the Eurostat baseline projection, by 2050 this ratio is expected to reach $60 \%$, compared to $51 \%$ in Germany, $46 \%$ in Ireland and $40 \%$ in the UK and Norway (Fig. 3.2; see Fries-Tersch et al. 2017, Fig. 15 for similar evidence regarding OADR 65+/20-64 in 2030).

While at the start of the twenty-first century (covering the period 2000-2016) Latvia has been a country of labour emigration, in the twentieth century Latvia saw periods of economically motivated immigration, times of humanitarian catastrophes

\footnotetext{
${ }^{2}$ Latvia's TFR was well below that found in most destination countries in 2000-2014 but is recovering since and is expected to stabilise at about 1.85.
} 


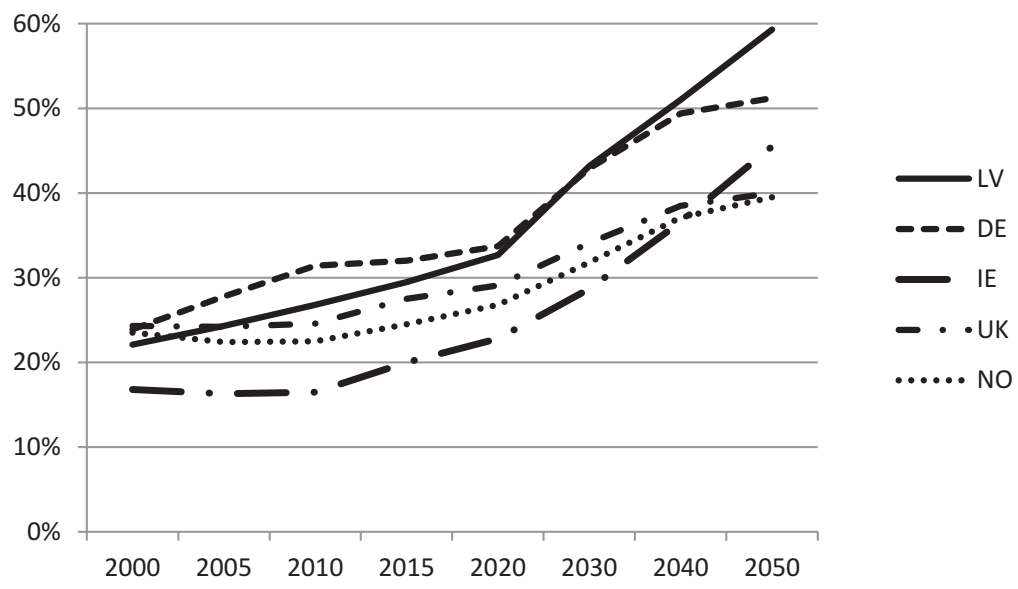

Fig. 3.2 Old age dependency ratio 2000-2015 and forecast for 2020-2050. Latvia and the main destination countries of Latvian emigrants. (Source: Eurostat data and main scenario projections. Note: The old age dependency ratio (OADR) is the ratio of population aged $65+$ to those aged 15-64)

and associated outflows of refugees and displaced persons, as well as mass deportations during periods of occupation and episodes of ethnically and politically driven emigration. There was also mass immigration of labour and military personnel which was centrally planned by the Soviet regime and, in addition, immigration of their families.

This chapter starts with a brief history of the main population flows (migration, refugees and deportation) from and to Latvia in the twentieth century before describing the scale, main destinations and dynamics of emigration in the early twenty-first century, as well as its effect on the size and demographic potential of the population. It proceeds by analysing the four waves of recent emigration:

(i) The pre-EU accession wave, 2000-2003;

(ii) The post-accession wave, 2004-2008;

(iii) The crisis-driven wave, 2009-2010 and

(iv) The post-crisis wave, 2011-2016.

The economic and social contexts of these emigration waves will be considered and a conceptual framework and set of hypotheses about their nature will be offered, using the human capital theory, the new economic theory of migration and the network theory, and institutional factors will be emphasised. The chapter also analyses changes in ethnic composition and educational profile of the four waves of emigrants.

Issues such as labour market outcomes and the life satisfaction of emigrants and returnees will not be considered, nor will the economic impact of emigration (see Hazans 2013, 2015d, 2016a, c, 2017a, b, 2018). 


\subsection{Latvian Migration in the Twentieth Century ${ }^{3}$}

In the nineteenth and early twentieth century Latvia was part of the Russian Empire. During the second part of the nineteenth century, after the end of indentured servitude and gradual lifting of other restrictions on human mobility, intensive ruralurban migration resulted in rapid urban growth. Riga's population almost quadrupled between 1863 and 1897. Growing cities attracted economic migrants from other parts of the Russian empire as well as from Germany and other European countries. At the same time, substantial numbers of Latvians moved outside Latvia's territory. By the end of the nineteenth century more than $10 \%$ of all ethnic Latvians were part of diaspora, including 112,000 in the Russian Empire (spread from provinces nearby Latvia to Siberia) and 35,000 living in the West.

'Migration systems' (see Bakewell 2014 and references therein) to and from Latvia kept working in the early part of the twentieth century. Russian, German and Jewish communities in Latvian cities and towns were strong and to some extent self-sufficient, and knowledge of Russian, German and other languages was widespread. These were important elements of inward migration systems which, in turn, strengthened these communities. By 1913, only one-third of Riga's residents were native born. Most of Riga's adult population spoke both Latvian and another language: $80 \%$ of men and two-thirds of women aged 20+, according to the 1925 census. Outside Riga this rate was lower, but it was still significant: above $50 \%$ among men and almost $30 \%$ among women. ${ }^{4}$

Apart from economic migrants, significant numbers of Jewish refugees from Russia, Ukraine, Belarus and Poland entered Latvia (and other Baltic provinces) in the 1880s and early twentieth century. This was to escape the growing anti-Semitism and violent pogroms. Economic reasons also played a role in Jewish migration to Latvia, but these are difficult to quantify. Many of these Jewish immigrants moved on, to the United States and Palestine.

Important elements of the migration systems outwards were the numerous wellorganised Latvian colonies, organisations and religious communities outside Latvia. There were also special preferential regime for new settlers in many Russian provinces, and by 1897, more than 70 colonies of Latvian farmers were established across the Russian Empire. Many Latvians settled in cities and found jobs as professionals, blue collar or service workers. Between 1897 and 1913, the number of Latvian schools outside the country more than trebled, increasing from 14 to 52, while the size of the Latvian diaspora increased to approximately 220,000 , including 45,000 in the West (mostly in the United States). Following the 1905 Revolution about 5000 political refugees and 2652 deportees constituted a relatively small but important part of emigration from Latvia at the beginning of the twentieth century.

\footnotetext{
${ }^{3}$ This section combines information compiled from various sources by Zelče (2011) and the National History Museum of Latvia (2016) with our own elaboration on data from the Central Statistical Bureau of Latvia (2016a, b, c, 2017a, b, c) and OECD (2008, 2017).

${ }^{4}$ Calculations by the author based on data from the Central Statistical Bureau of Latvia (2016c).
} 


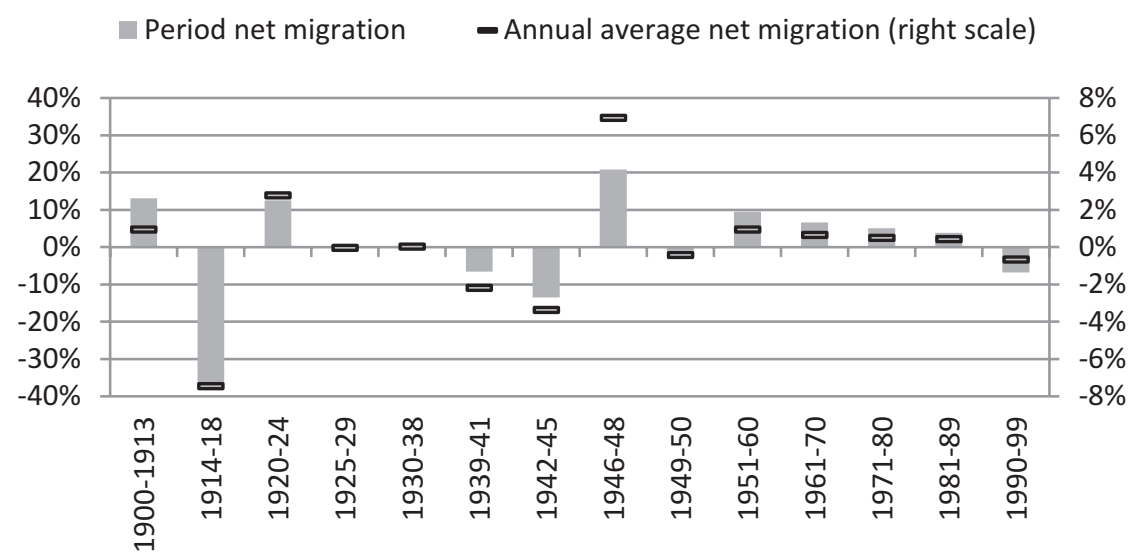

Fig. 3.3 Net migration and net migration rate by sub-period of the twentieth century ( $\%$ of the initial population). (Source: Data cited in Zelče (2011) and the National History Museum of Latvia (2016), Central Statistical Bureau of Latvia (2016a, b, 2017a, b), OECD (2017), and author's own calculation)

Despite intensive migration both to and from Latvia, the migration balance during the late nineteenth and early twentieth century was significantly positive. During the period 1900-1913, the increase in Latvia's population due to net migration was $13 \%$ (nearly $1 \%$ per annum) of the initial population, or 264,000 persons $^{5}$ (see Fig. 3.3).

During World War I and the Russian civil war, around one million Latvia's residents moved to other territories (mostly in Russia) as refugees, displaced persons, evacuees or after being mobilised into armed forces. In 5 years Latvia lost $37 \%$ of its population (Fig. 3.3). Around half died outside Latvia, while others settled in Soviet Russia, Estonia, Lithuania and Germany. Less than one-third returned after the war. Many former Latvian soldiers, known as 'Red Riflemen' settled in Russia after the war, serving in the new Soviet government's security forces or as Bolshevik Party functionaries, while others resumed their lives as civilians in some of the Latvian colonies or in cities.

In 1918, the independent Latvian state was created. Over the next 10 years, around 300,000 people returned to Latvia, most of them in the period 1919-1921. Net migration during the 4.5 years between the 1920 and 1925 censuses was 200,000 people, or $13 \%$ of the country's population in 1920 (Fig. 3.3). Political refugees and deportees accounted for a small but not negligible part of these migration flows. More than 10,000 people moved to Soviet Russia or were expelled from Latvia for engaging in 'anti-state activities', while around 15,000 moved to Latvia fleeing the Soviet regime.

The period between 1925 and 1938 was characterised by the low intensity of migration. The annual average net migration rate was $0.04 \%$ in $1925-1929$ and

${ }^{5}$ Ironically, 100 years later (in 2000-2014), Latvia lost the same number of people to migration. 
$0.02 \%$ in $1930-1938$ (Fig. 3.3). Land reform largely eliminated the motivation among farmers to emigrate. The economic situation was perceived as good by the majority of the population. Self-employment accounted for more than $60 \%$ of total employment, while the unemployment rate was below $1 \%$. Nevertheless, about 5000 people moved from Latvia to the US between 1920 and 1939, while 2700 moved to Brazil and 4500 to Palestine.

The largest Latvian diasporas in the 1920s and 1930s were found in Soviet Russia $(151,400$ according to the 1926 census), the US $(38,000)$, Lithuania $(30,000)$, Estonia (12,300) and Brazil (7000).

From a migration perspective, the decade between 1939 and 1949 can be described as an 'era of displaced persons and refugees' for Latvia (Zelče 2011, p. 62). In 1939-1940, 51,000 ethnic Germans left for Germany in a 'repatriation' programme launched by Hitler's government. Another 10,500 Germans followed during the winter of 1941, after Latvia's incorporation into the USSR. Overall, these two waves reduced Latvia's population by $2.6 \%$.

On 14 June 1941, 15,424 people ( $0.8 \%$ of Latvia's population) were deported as 'class enemies' by the Soviet regime. Some were arrested and sent to camps in Northern parts of Russia. Administrative deportees were settled in Siberia, the Kazakh Republic and elsewhere. About $40 \%$ of the 1941 deportees died in camps or in exile. In June 1941 Germany invaded the USSR and Latvia was occupied by the Nazis, prompting around 53,000 people to leave Latvia for other regions of the USSR; some were evacuated while others found their way as refugees. Overall, in the period 1939-1941 Latvia lost about $6.6 \%$ of its population as repatriates, deportees and refugees (Fig. 3.3).

According to conservative estimates, another 242,000 people (13.4\% of the population) were lost due to different types of forced migration in the period 19421945. This figure covers:

(i) Those who were mobilised and sent outside Latvia in the ranks of the Nazi army or the Red/Soviet Army (excluding those who were killed during the war);

(ii) Those who chose (or were forced) to work in Germany during the war;

(iii) Refugees who left Latvia for Germany and other Western countries (Austria, Belgium, Denmark and Sweden) at the end of the war (or immediately after it) to avoid life under the Soviet regime.

The total also accounts for return migration from other parts of the Soviet Union which started in 1945 (estimated inflow in that year is 15,000 persons).

Most refugees, as well as members of the Latvian Legion who had served as soldiers in the German army, ended up in Displaced Persons camps, but in 1947 a programme began to close these camps, and refugees began to move to countries which were ready to receive them. This was the starting point of the post-war wave of the Latvian diaspora. About 45,000 went to the US; Australia and Canada received about 20,000 each; 17,000 ended up in the UK; 15,000 settled in Germany, 4000 in Sweden, 5000 in South America and 5000 elsewhere. One of the key elements facilitating the respective migration systems was the International Refugee Organisation 
(IRO 1947-1951), succeeded by the UNHCR, as well as Latvian organisations existing previously in the host countries.

Latvia, re-occupied by the Soviet Union since 1945, experienced a mass return of refugees and military personnel between 1946 and 1948, as well as the inflow (partly centrally managed) of migrants from other parts of the Soviet Union. These factors increased Latvia's population by more than 323,000 , or $21 \%$, in just 3 years (Fig. 3.3).

Return migration and immigration continued in 1949-1950, but the migration balance in this period was negative (equalling a loss of almost 16,000 persons, or $0.8 \%$ of the population) due to the forced deportation of 42,125 people $(2.2 \%$ of population) to Siberia or the Far East of the USSR on March 25, 1949. Later (mostly in 1956-1957, after the denunciation of Stalinist repression at the 20th Congress of the Communist Party), around $80 \%$ of those exiled in 1949 returned to Latvia (Central Statistical Bureau of Latvia 2017b).

Between 1951 and 1990, immigration into Latvia from other parts of the Soviet Union continued at high (although decreasing) rates: from 9.5\% in 1951-1960 to $6.6 \%$ in $1961-1970 ; 5.1 \%$ in $1971-1980$ and $3.8 \%$ in $1981-1989$ (Fig. 3.3). As the result, the share of ethnic Latvians in Latvia's population fell from $77 \%$ in 1935 to $52 \%$ in 1989.

Key elements which kept this migration system going included:

1. Centralised decision making on the allocation of resources, including the labour force;

2. Mandatory prescription of their workplace for university graduates for a period of at least 3 years;

3. Russian language as the official language in all parts of the Soviet Union;

4. The standard of living being higher in Latvia (and other Baltic republics) than elsewhere in the Soviet Union (except Moscow and Leningrad).

Emigration from Latvia under the Soviet regime was almost impossible. The exception (which became possible under international pressure) was the emigration of Jews: about 13,000 emigrated to Israel, Germany, the US and Canada between 1968 and 1980, and another 16,000 left in the subsequent 9 years up to 1989. Some Poles and Germans were also able to emigrate thanks to family reunification agreements.

In the last decade of the twentieth century, after the restoration of Latvia's independence in 1990, the country lost $6.7 \%$ of its population to migration in two parallel processes (Figs. 3.3 and 3.4).

First, especially in the first half of the decade, there was a vast outflow of the Russian-speaking population to Russia and, to a smaller extent, other CIS countries. ${ }^{6}$ For some of these emigrants this was, in fact, forced family migration: significant numbers of Soviet Army staff had to leave Latvia, and their family members joined them. For many others, emigration was triggered by dramatic changes in a number of fundamental life domains - changes which affected their social and

${ }^{6}$ The CIS included the republics of the former Soviet Union except for the Baltics. 


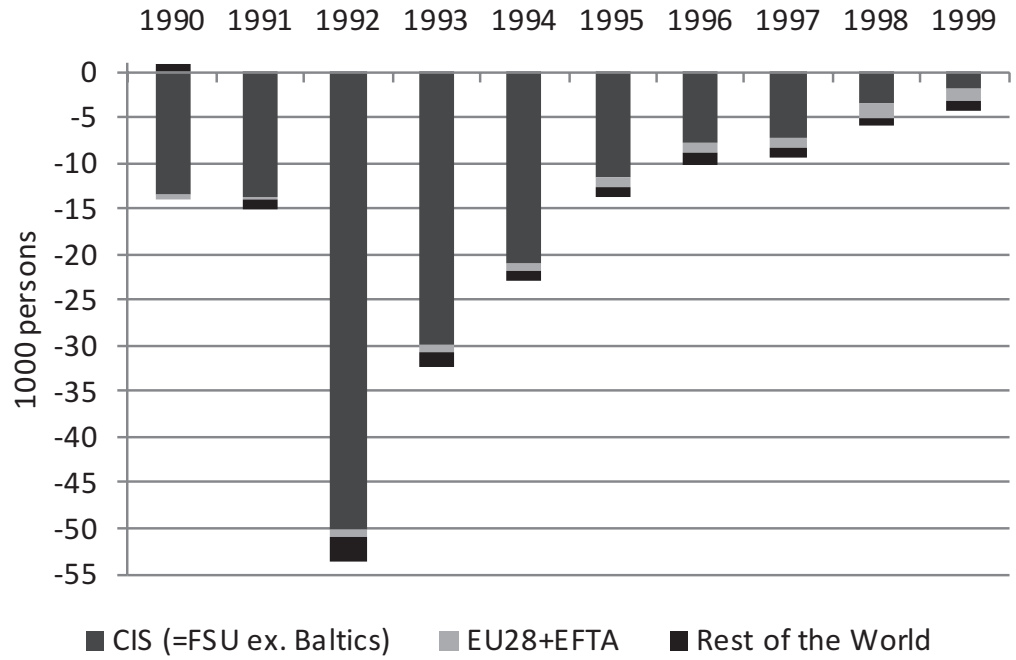

Fig. 3.4 Latvia's net migration 1990-1999, by destination. (Source: Central Statistical Bureau of Latvia (2017c, d) and statistical offices of EFTA countries)

economic status, self-perception, relationships with others and perspectives on life. The political regime changed from being a global superpower, a multi-national Communist empire with the Russian language being both the lingua franca and the main official means of communication, to a neo-liberal national state previously occupied by that very superpower, where the official communication between all state and municipal institutions and the civil and business population was only in the Latvian language. The change of language substantially weakened the labour market position of those without good Latvian language skills (Hazans 2010, 2011a). In addition, many of the large manufacturing enterprises and research institutes closed down in the early 1990s. Some of them had previously been part of the Soviet military-industrial complex which had employed large numbers of the post-war immigrants and their descendants. Finally, citizenship of the new independent state was granted only to those who were citizens of the Latvian Republic between 1918 and 1940 and their descendants, while others were offered a choice between a Latvian 'non-citizen' passport or applying for Russian citizenship (see Muižnieks 2006). These 'push' factors, together with strong family, social and professional networks the post-war immigrants to Latvia had in Russia and other CIS countries, as well as their relatively easy access to Russian citizenship, contributed to the rise of the Latvia-CIS migration system in the 1990s. Transformation of all 15 Soviet republics into independent nation states also worked as a 'pull' factor, as ethnic Ukrainians, Uzbeks, Kazakhs, etc. living in Latvia in Soviet times considered moving back to their respective countries. 


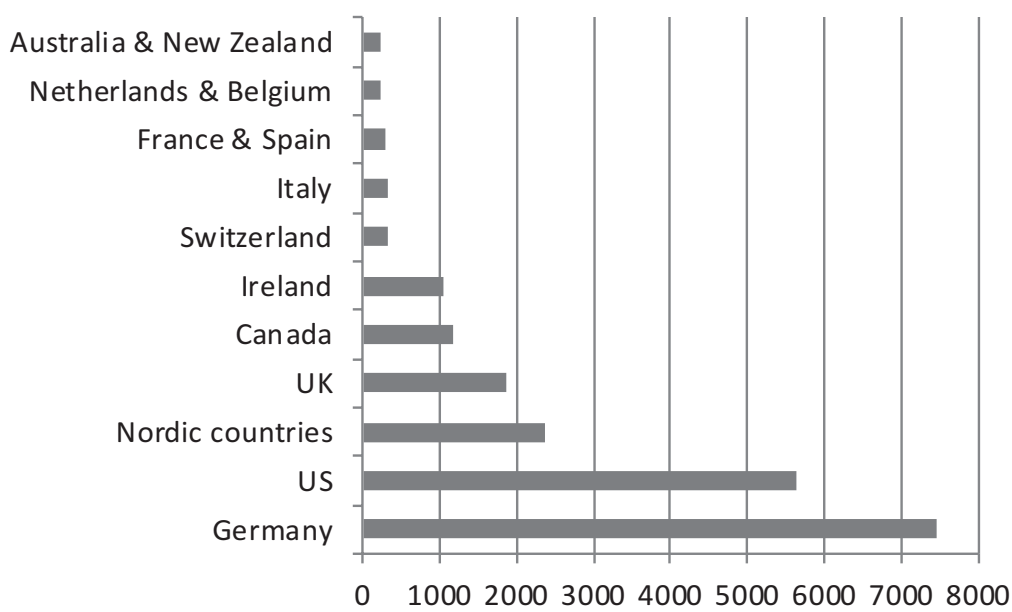

Fig. 3.5 Post-Soviet emigrants from Latvia in OECD countries by the end of the twentieth century. (Source: $\operatorname{OECD}(2008,2017)$ and author's own calculation. Note: UK data refer to 2001. Data for Germany refer to all nationals of Latvia residing in Germany by the end of 1999 and therefore might also include some Soviet-era emigrants)

Secondly, the fall of the Iron Curtain allowed for pioneer emigration (Bakewell et al. 2011) to the West. This was mostly economically motivated, but also included student migration, international family formation and so on. Both ethnic Latvians and Russian-speakers were found among these pioneers. Some of them relied on help and information support from the rich social infrastructure created in the Western countries by the post-war Latvian refugees (see Zelče 2011, pp. 64-66 and references therein) or from less formal social networks among Russian-speaking emigrants from the Soviet Union in Germany, the United States, Canada, Australia and elsewhere. Other pioneers were able to find their own way themselves or by using professional or business contacts in the West acquired while working in Latvia. In the early 1990s, the majority of emigrants to the West went to destinations outside Europe, but it was the other way around in the late 1990s (Fig. 3.4). By the end of the twentieth century, the post-Soviet Latvian diaspora in OECD countries accounted for about 21,000 people (see Fig. 3.5 for details).

Finally, there was some return migration in the 1990s of ethnic Latvians (both from the West and from the CIS countries) to Latvia after independence was restored.

During 1989-1999, the net migration of ethnic Latvians was positive at 1.8\%, while the net migration of the minority population was negative at $-16.8 \%$ (Table 3.1). The population share of ethnic Latvians increased from $52 \%$ in 1989 to $57.7 \%$ in 2000 . 
Table 3.1 Net migration of Latvia's population by main ethnic groups, 1989-2016

\begin{tabular}{l|l|l|l|l}
\hline & $1989-1999$ & $2000-2010$ & $2011-2016$ & $2000-2016$ \\
\hline Total & $-7.1 \%$ & $-7.9 \%$ & $-3.7 \%$ & $-11.3 \%$ \\
\hline Latvians & $1.8 \%$ & $-5.5 \%$ & $-3.1 \%$ & $-8.4 \%$ \\
\hline Minorities & $-16.8 \%$ & $-11.2 \%$ & $-4.7 \%$ & $-15.4 \%$ \\
\hline Russians & $-18.0 \%$ & $-11.8 \%$ & $-4.8 \%$ & $-16.0 \%$ \\
\hline Ukrainians & $-31.3 \%$ & $-13.1 \%$ & $-2.8 \%$ & $-15.5 \%$ \\
\hline Belarussians & $-13.1 \%$ & $-9.8 \%$ & $-2.0 \%$ & $-11.6 \%$ \\
\hline Poles & $\ldots$ & $-7.8 \%$ & $-5.4 \%$ & $-12.8 \%$ \\
\hline Lithuanians & $\ldots$ & $-7.7 \%$ & $-4.1 \%$ & $-11.5 \%$
\end{tabular}

Source: Calculation based on the Central Statistical Bureau of Latvia (2017e, f)

It is likely that data for 1989-1999 over-estimate the absolute net migration of Latvians and minorities because, during this period, Soviet passports were changed to Latvian ones, and many of those born in ethnically mixed families changed their ethnicity from Russian to Latvian, Polish, etc. Data for 2000-2016 rely on the 2011 Census data and therefore should be considered with a degree of care (see Hazans 2013, p. 68, p. 72, pp. 109-110). The data refer to the total migration rather than the migration of nationals

\subsection{Emigration of Latvia's Nationals in the Early Twenty- First Century: The Context, Scale and Main Destinations}

Emigration from Latvia in the early twenty-first century was to a large extent shaped by two milestones. First, EU accession in 2004 gave Latvian citizens immediate access to the labour markets of the UK, Ireland and Sweden (as well as of all the new member states), while the other EU-15 countries gradually opened their labour markets during 2006-2011. This new possibility attracted thousands of Latvians. However, the economic crisis in Latvia of 2008-2009 and its economic and social consequences sent even more Latvians abroad, including those who had never considered such a move before.

The driving forces of emigration in the early twenty-first century and the changing profile of emigrants are discussed in greater detail in Sects. 3.5 and 3.6. Here we focus on developments regarding the scale and main destinations of that emigration.

Figure 3.6 presents the outflows of Latvia's nationals (i.e. holders of Latvian passports: both citizens and non-citizens) to the main OECD destinations and compares the data from receiving countries with the official Latvian emigration statistics. Due to problems in the 2011 Census (see Hazans 2013, p. 68, p. 72, pp. 109-110 for details) the official data have been obtained by an indirect method and it appears that they strongly over-estimate outflows in 2000-2003 and 2008 but under-estimate emigration during the post-accession period 2005-2007, as well as during the postcrisis years 2010-2016.

Before Latvia's accession to the EU, emigration from Latvia occurred at rather low rates (about $0.25 \%$ of population per annum), but immediately after accession in 2004, the UK, Ireland and Sweden opened their labour markets for nationals of the new member states, and outflow from Latvia almost tripled. It increased further 


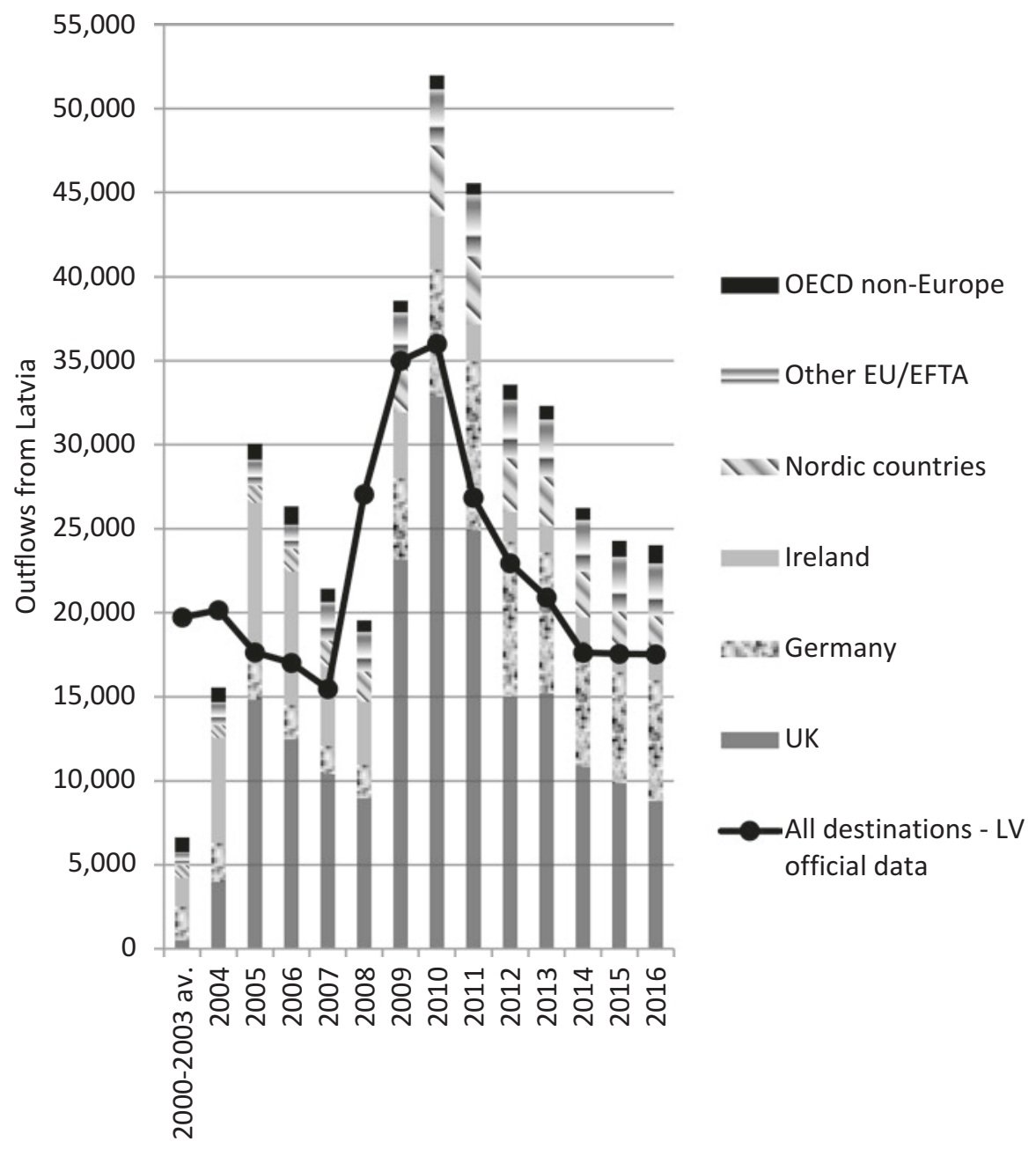

Fig. 3.6 Gross outflows of Latvian nationals to main OECD destinations, 2000-2016 (destination countries' data vs. official Latvian statistics). (Source: Eurostat and OECD (in some cases also national statistics) data on immigration of foreigners by nationality; Ireland and the UK data on allocation of social security numbers. Note: Due to data limitations, Latvian official data for 20002010 refer to total outflows (including foreigners))

in 2005, most likely due to the network effect, and after that never fell below $1 \%$ of the population per annum. The outflows reacted to economic developments in Latvia in a predictable way: the flow declined during growth periods (2005-2007 and 2011-2016) but increased explosively during the crisis, reaching $2.5 \%$ of the population in 2010.

There were also dramatic changes in the shares of different destinations in the total outflow (see Fig. 3.6) reflecting both institutional and economic developments. In 2004, Ireland was the destination of $40 \%$ of emigrants, followed by the UK with 
$26 \%$; both countries sharply increased their shares compared to the pre-accession period due to the opening of their labour markets. In 2005 the UK almost doubled its share, while Ireland's share fell to $30 \%$ and further to about 20\% in 2007-2008; meanwhile, the share of non-English speaking countries (many of which opened their labour markets in 2006-2007) increased. With the onset of the economic crisis which strongly hit Ireland's labour market, Ireland's share continued its decline and after 2011 never went above 5\%.

Since 2005, the UK has kept the largest share of Latvian emigrants - almost half of them in 2005-2008 and more than 60\% in 2009-2010. However, with the opening of the German labour market in 2011, the share going to the UK started to decline; it was just above 40\% in 2014-2015 and dropped below that level in the Brexit referendum year, 2016. Uncertainty surrounding the post-Brexit status of labour migrants from Latvia and other new member states during the period after the Brexit referendum (see e.g. Lulle 2018, Lulle et al. 2018) has made the UK a less popular choice among emigrants from Latvia.

Outflow from Latvia to Germany was rather stable in absolute terms in 20002008 , but its share went down from $30 \%$ in the pre-accession period to $8 \%$ in 2005 2007 and $10 \%$ in 2008. With the beginning of the crisis and especially since 2011, the outflow to Germany started to increase. Recently its share is about $30 \%$. The shares of the other main destinations in the post-crisis period are also relatively stable: about $10 \%$ of emigrants go to the Nordic countries; slightly more go to other EU/EFTA countries, and less than 5\% go to non-European OECD countries.

Further evidence on the dynamics of emigration during 2000-2016, this time in terms of net emigration, is presented in Table 3.2, which compares four periods covering 4 or 5 years each based mostly on the statistics of the receiving countries.

We find that the effective annual rate of net migration has doubled in the postaccession period compared to the pre-accession one, and more than doubled again during the crisis and first two post-crisis years (2009-2012) compared to the postaccession wave. During the latest post-crisis years (2013-2016) the rate was slightly higher than in the post-accession period.

Table 3.2 Net emigration of Latvia's nationals, 2000-2016

\begin{tabular}{l|l|l|l}
\hline & $1000 \mathrm{~s}$ & $\begin{array}{l}\text { Percent of the population at } \\
\text { the beginning of 2000 }\end{array}$ & $\begin{array}{l}\text { Effective annual rate of net } \\
\text { emigration }\end{array}$ \\
\hline $2000-2003$ & 33.5 & $1.4 \%$ & $0.35 \%$ \\
\hline $2004-2008$ & 75.9 & $3.2 \%$ & $0.65 \%$ \\
\hline $2009-2012$ & 125.0 & $5.3 \%$ & $1.41 \%$ \\
\hline $2013-2016$ & 56.9 & $2.4 \%$ & $0.67 \%$ \\
\hline $2000-2016$ & 291.4 & $12.2 \%$ & $0.76 \%$ \\
\hline
\end{tabular}

Source: Eurostat, OECD, national statistical offices and author's own calculation

Net emigration is the difference between emigration and immigration (i.e., the opposite of net migration). The effective annual rate of net emigration is a constant emigration rate which, if applied every year, would result in the given net outflow during the period 


\subsection{Emigration and Demographic Potential}

This section discusses the impact of emigration on Latvia's population structure and demographic potential. Like elsewhere in Central, Eastern and South-Eastern Europe (see IMF 2016, p. 12), those who left have been younger than those who stayed. However, due to unusually high emigration rates, the shrinking of the young and middle aged cohorts in Latvia has been particularly pronounced (Table 3.3), thus accelerating population ageing and distorting the age structure.

In the 10 years between 2004 and 2014, the cohorts aged 15-19, 20-24 and 25-29 years in 2004 lost $21.7 \%, 17.9 \%$ and $14.4 \%$ respectively of their members to migration, while the overall loss of population due to migration during this period was just $9.4 \%$.

Even when comparing adult working-age individuals only, the emigrant population appears to be much younger than the stayers (Fig. 3.7).

In addition to the falling size of the reproductive age cohorts, Latvia's demographic potential is undermined by the fact that - at least in the post-crisis period families with children or planning to have a child are more likely to emigrate, as shown in Fig. 3.8. This figure is based on a representative household survey conducted in Riga in 2012.

In a more general setting, Hazans (2018, Table A5) using four waves (20132016) of representative surveys of Latvia's population, shows that among people aged 18-34, those having a child under 18 in the family (with other things being equal) are significantly more likely to move to work abroad in the near future. Among men, the same effect was also found at the end of the crisis period; namely late 2010 to early 2011(see Hazans 2013, Table 4.8).

Figure 3.9 compares the proportion of emigrants living abroad with children aged below 18 - or having children this age in Latvia with the proportion of stayers living with children under 18 in Latvia. In both cases, the children of the emigrant or stayer and their partner's children are accounted for.

It appears that emigrants of both genders aged 18-24 are much more likely to have children than their counterparts in Latvia, while the reverse is true among those

Table 3.3 Net migration of Latvian nationals by selected age cohorts, 2004-2014

\begin{tabular}{l|l|l|l}
\hline Age, 2004 & $2004-2009$ & $2009-2014$ & $2004-2014$ \\
\hline Total & $-3.2 \%$ & $-6.4 \%$ & $-9.4 \%$ \\
\hline $15-19$ & $-7.9 \%$ & $-15.0 \%$ & $-21.7 \%$ \\
\hline $20-24$ & $-8.1 \%$ & $-10.6 \%$ & $-17.9 \%$ \\
\hline $25-29$ & $-5.4 \%$ & $-9.5 \%$ & $-14.4 \%$ \\
\hline $30-34$ & $-4.6 \%$ & $-6.6 \%$ & $-10.9 \%$ \\
\hline $35-39$ & $-4.2 \%$ & $-5.7 \%$ & $-9.7 \%$ \\
\hline
\end{tabular}

Net emigration by cohort has been calculated from the Latvian LFS microdata as the decrease in the annual average size of selected cohorts over two five year periods (2004-2009 and 20092014), less age-specific mortality over relevant periods. Total net migration is that over five-year periods 2004-2008 (see Table 3.2) and 2009-2013 (estimated by Table 3.2 method) 


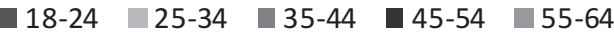

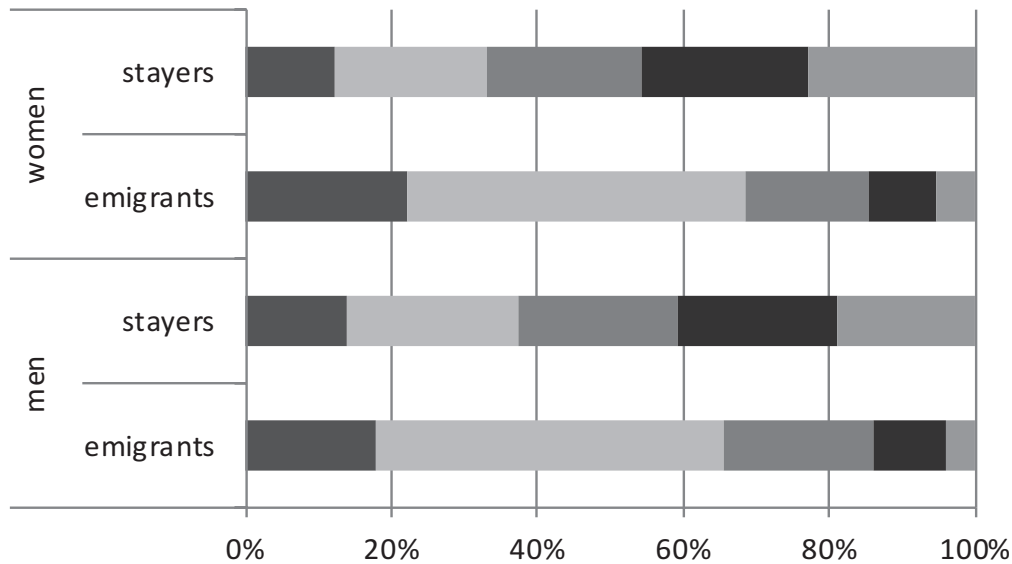

Fig. 3.7 Age distribution of adult working-age emigrants from Latvia and stayers therein, 2014. (Source: Calculation with microdata of The Emigrant Communities of Latvia survey and the Latvian Labour Force Survey 2014)

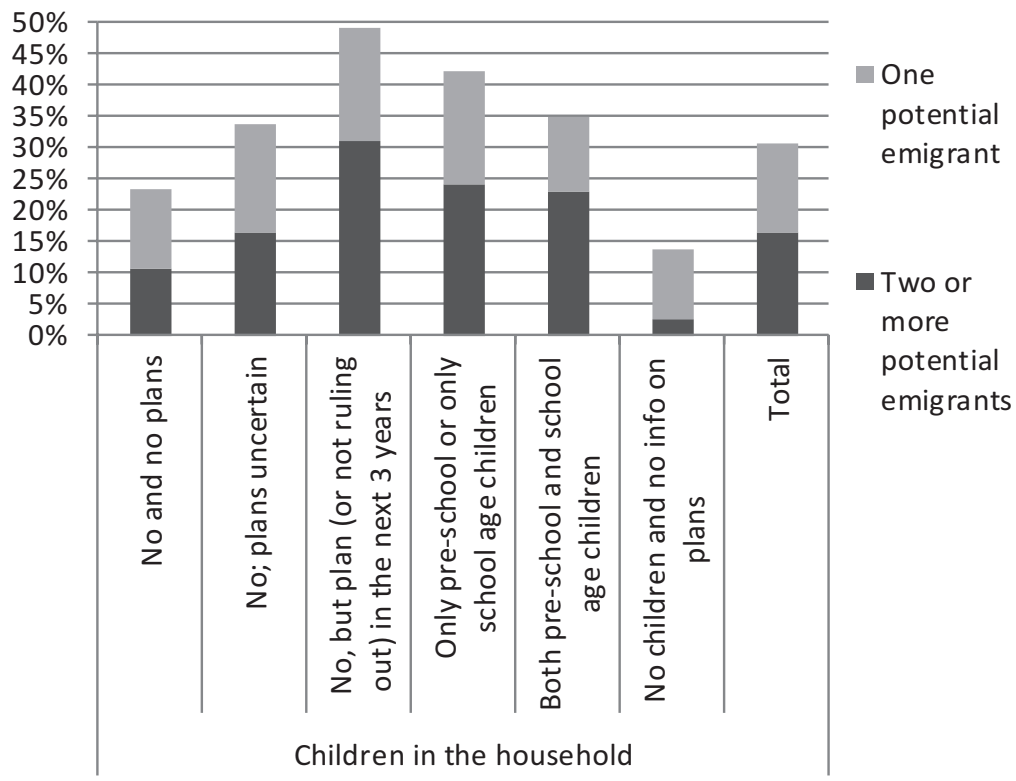

Fig. 3.8 Share of households with one or more potential emigrants, by presence of children and plans to have children in the next 3 years. (Source: Hazans (2014, p. 10), based on a representative survey of households in 2007) 


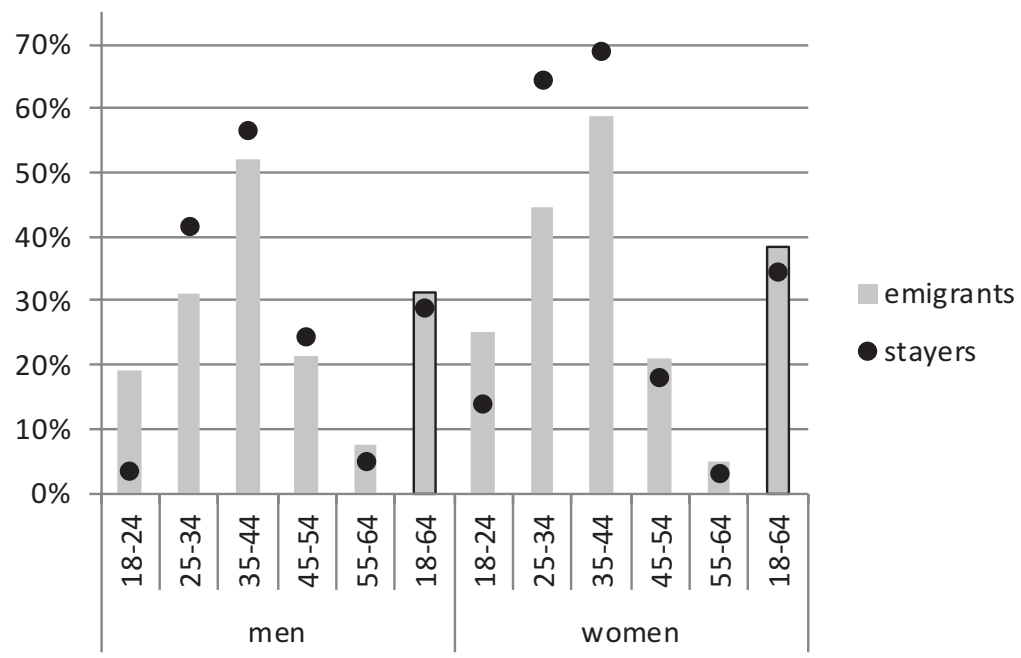

Fig. 3.9 Incidence of having children aged below 18 among emigrants from Latvia and stayers therein, 2014, by age and gender. (Source: Calculation using microdata of The Emigrant Communities of Latvia survey and the Latvian Labour Force Survey 2014. Note: For emigrants: the children were living in the same household abroad or were left behind in Latvia. For stayers: the children were living in the same household in Latvia. Emigrants'/stayers' own and their partner's children are included)

aged 25-44. In the age group 45-64, there is only small difference between emigrants and stayers. Overall, in 2014 about 30\% of male emigrants aged 18-64 and about $40 \%$ of their female counterparts had adolescent children. Among stayers these proportions were slightly lower, mainly due to smaller shares of reproductive age cohorts (Fig. 3.9).

\subsection{Four Waves of Emigration in the Early Twenty-First Century}

The history of emigration from Latvia during 2000-2016 can be divided into four episodes: ${ }^{7}$

(i) The pre-accession period, which we denote as 2000-2003;

(ii) The post-accession period of economic growth, which we refer to as 2004-2008;

(iii) The crisis period: 2009-2010;

(iv) The post-crisis period: 2011-2016.

\footnotetext{
${ }^{7}$ This section builds on the author's previous work (Hazans 2011b, 2012, 2013, 2016a).

${ }^{8}$ The crisis hit Latvia at the end of 2008, but its effect on emigration first appeared only in 2009.
} 
During this relatively brief time, the main reasons for emigration, the rates of emigration and the most popular destinations for emigration - as well as the profile of the emigrants and their plans - have changed substantially several times.

\subsubsection{The Conceptual Framework}

Economic and sociological literature provides the conceptual framework for understanding migration patterns and the way these patterns change over time in response to economic, political and social developments in the source and destination countries. According to the (neoclassical) human capital model of migration (Borjas 1987, 1999; Sjaastad 1962), an individual decides to move if the expected utility in the destination country, net of the monetary, effort and psychological costs of migration, exceeds utility in the home country.

Apart from the earnings expected at home and abroad, this calculation should account for other factors affecting utility - job finding and job losing probabilities, the emigrant's legal status, career prospects, working and living conditions, the generosity of the social security system, social and cultural norms, perceived life prospects for children, etc.

The New Economics of Migration (Stark and Bloom 1985) emphasises that migration decisions are often taken by families, households or even larger groups, rather than individuals, and stresses the role of risk, both at home and abroad. Uncertainty has to be considered as the location-specific factor reducing utility; it also has to be taken into account from the perspective of the diversification of the family portfolio of human capital.

Furthermore, the New Economics of Migration points to the role of relative income in migration decisions as opposed to absolute income, and shows that falling income differentials may not discourage migration.

Migration systems theory (Bakewell 2014; de Haas 2010; Mabogunje 1970) and social network theory (Carrington et al. 1996) emphasise transnational links between people, families and communities which, along with other circumstances, support and sustain clustered migration flows.

\subsubsection{The Pre-accession Wave: Personal Characteristics}

Before joining the EU, unemployment in Latvia was at a two-digit level, while GDP per capita (at PPP) was well below $50 \%$ of the EU-15 average. The earnings of an unskilled worker in the UK, Nordic countries or Germany looked very attractive in comparison with average earnings in Latvia. These strong push and pull factors resulted in a sizeable emigration potential, which was larger among the Russianspeaking minority population (Hazans 2012, Fig. 6.2). 
However, actual emigration rates in the early 2000s were low, due to the need for work and residence permits, but also because of high transportation and communication costs, the limited availability of good quality internet connections and the absence of convenient, extensive information sources regarding job opportunities and living and working conditions abroad. During the 4-year period before accession (2000-2003), the net outflow of Latvia's nationals was $1.4 \%$ of the initial population (Table 3.2).

To understand who were the likely movers in the pre-accession period, one should notice that migration costs were lower for people with professional or at least private contacts in potential destinations, with good foreign language and ICT skills, and the opportunity to use the internet for private purposes at a workplace. Clearly, all these attributes are found more often among university graduates. On the other hand, the absence of a favourable legal framework, restricted access to reliable information and difficulties in searching for jobs 'from overseas', coupled with a high risk of fraud by domestic firms recruiting workers for jobs abroad in the early 2000s, suggested that emigration required high degrees of initiative and the willingness to accept risk. However, a less risky, less initiative-led option was to access migration networks from previous waves of migration to the US, Canada, Australia, Sweden and Germany, as well as from and to Russia, Ukraine and Belarus.

Most emigrants - driven by their own initiative rather than their networks - were oriented towards relatively new directions, mainly the United Kingdom and Ireland, where the language barrier for them was lower than in the rest of the EU, while migration costs were lower than to other English-speaking countries. The preaccession wave of emigration thus featured substantial positive selectivity regarding human capital and other personal characteristics, an over-representation of Russian speakers and a high degree of geographical diversification.

\subsubsection{The Post-accession Wave: Institutional and Market Factors}

During Latvia's first 5 years in the EU, i.e., before the effect on migration patterns became apparent of what is now called the 'Great Recession', migration flows were shaped mainly by institutional and market factors.

The gradual implementation of the free movement of labour within the EU (see Kahanec et al. 2016, Table 1) substantially lowered both the monetary and nonmonetary costs of searching for a job abroad and the process of migration, as well as the human capital threshold (in terms of skills, initiative and risk-taking) for labour migration. Together with a high - and growing - demand for migrant labour in the EU15, this triggered a sharp and, to a large extent, persistent increase in emigration rates (see Table 3.2 and Fig. 3.6). This in turn lowered migration costs further via migrant networks and the rich social and media infrastructure existing within the rapidly growing Latvian diasporas in Ireland, the UK, Sweden, Germany 
and elsewhere in the 'old' member states (see Hazans and Philips 2010; OECD 2012). Another significant factor was the drop in the price of international telecommunications and air travel due to growing markets and technological change.

In addition, strong pull factors were at work, such as higher incomes and better working conditions abroad, as well as factors relating to family and/or friends. Together, these factors covered about $80-90 \%$ of the potential emigrants from Latvia (Hazans 2012, Table 6.3).

On the other hand, due to strong economic growth in Latvia, the unemployment rate was falling while real income was rising (Hazans 2016a, Fig. 1), gradually reducing the expected gains from emigration. Thus, during the second part of the post-accession period, the motivation to move abroad driven by push factors was falling, and the motivation to return among recent emigrants was on the rise.

Overall, in the 5 years post-accession Latvia lost $3.2 \%$ of its population to emigration (Table 3.2).

In the migration-friendly post-accession environment, emigrants' self-selection in terms of human capital was driven mainly by their expected gains in terms of income and working conditions rather than the individual's comparative advantage in lowering migration costs. These gains were, on average, greater for people with secondary education or lower (see Hazans 2016a, p. 310 for details). Hence, one should expect that the post-accession emigrants from Latvia were less well educated as a group than pre-accession ones, either in an absolute (composition) or relative (selection) sense, or both.

The effect of ethnicity and citizenship on the propensity to emigrate has also changed. Due to strong economic growth and the labour shortage caused by emigration (Hazans and Philips 2010, Sect. 7 and Fig. 12), as well as a gradual improvement in state language skills among young and middle-age minorities (Hazans 2010, Fig. 3, 2011a, Tables 8.8-8.9), the labour market position of ethnic minorities in 2004-2007 was steadily improving (see Hazans 2016a, Fig. 6), thus weakening important push factors for this group. On the other hand, a substantial part of the minority population - those without Latvian citizenship - was not covered by the legal provisions for the free movement of labour within the EU. This worsened their mobility opportunities in comparison to citizens.

The above considerations suggest that, compared with the pre-accession period, post-accession emigrants from Latvia feature a significantly lower proportion of ethnic minorities, especially non-citizens.

Another important feature of this emigration wave is its mixed nature. While migration was to a large extent short-term and/or cyclical (see e.g. Hazans and Philips 2010, Sect. 6, Figs. 9 and 10), the Latvian diasporas abroad were steadily growing (Hazans 2015a, p. 11), suggesting that many emigrants have chosen to settle in destination countries. 


\subsubsection{Crisis-Driven Emigration: Lost Jobs, Lost Perspectives, 'the New Movers', and the Shift Towards Permanent Emigration}

During the years of the Great Recession (2009-2010), significant economic push factors were at work; mainly joblessness and wage cuts, but also the implied inability to pay back credit.

The psychological shock was no less painful: a large proportion of people of working age, including those who managed to keep their jobs, lost confidence in the future (Hazans 2011b, 2013). Consumer confidence, satisfaction with the government and trust in the parliament dropped dramatically (Hazans 2015a, pp. 3-4; 2016a, Fig. 2).

Finding a Job in Western Europe was not as easy as before the crisis. The role of diasporas and informal networks increased as a consequence. Yet it was much easier than in Latvia. The rate of unemployment was very low in Norway, the Netherlands and Austria, and modest in the UK, Germany, Sweden and Denmark. The lifting of restrictions on the free movement of workers from EU8 countries by Belgium, Denmark and especially Norway from May 2009 further facilitated labour migration to these destinations.

Moreover, nominal earnings continued to rise across the old member states, while real earnings did not decline (European Commission 2011, graphs I.1.8, III. A3.5). Thus, the expected gains from emigration in terms of employment and earnings increased in comparison to the pre-crisis period.

In addition, as long-term joblessness was becoming more widespread in Latvia, the issue of social protection, which previously had been neglected by the middle class, gained importance as a factor driving migration decisions. A feature of Latvian social security was a very low income replacement rate for the long-term unemployed through unemployment benefit, even when social assistance and housing benefits are accounted for (European Commission 2011, graphs II.2.3- II.2.4).

Moreover, child benefits in Latvia were extremely low in comparison with those paid in the main destination countries of Latvian emigrants.

High and persistent unemployment, a weak social security system, lost perspectives - these were the factors that converged to make emigration a real option in the minds of many Latvians, even those who had not considered such a possibility before (Hazans 2011b, 2012, 2013; McCollum et al. 2017). There were two kinds of these 'new movers': (i) individuals who were inherently not very mobile for whom this was the only way out of financial difficulties; and (ii) people who were not satisfied with developments in Latvia and with their own prospects there, even if they were not experiencing economic hardship at that moment. In this way, the post-accession migration system was substantially transformed and expanded. 
Unlike the pre-accession emigrants, most of those who left during and after the crisis were not risk-takers. On the contrary, they perceived staying as too risky, and the destination countries were seen as a safe haven. This implied a strong shift from the temporary emigration of 'breadwinners' towards the long-term or permanent emigration of entire families. The post-crisis emigrants, as opposed to the pre-crisis group, are much more oriented towards long-term or permanent emigration, are interested in legal employment and social security and are more likely to move as entire families (Hazans 2013, Table 4.6). According to The Emigrant Communities of Latvia survey, by 2014 about $70 \%$ of emigrants had lived in their host countries for three or more years (Hazans 2018, Fig. 4).

The longer emigrants live in a host country and the higher their education level, the smaller the proportion is of them with a spouse, partner or adolescent child left in Latvia, and the larger the proportion that is living with a partner and/or a child or children aged under 18 abroad (Fig. 3.10).

Econometric analysis of the return intentions of emigrants (Hazans 2015b, c) shows that having family members remaining in Latvia positively affected the probability of their return. Conversely, having their family living with them abroad negatively affected the probability of the emigrant's return - i.e., made them more likely to stay abroad.

By 2014, two-thirds of high-educated emigrants lived abroad with either a partner or a child aged under 18 (or both), and only $15 \%$ had a partner or a child left in Latvia. For medium-skilled emigrants these proportions were, respectively, 59\% living abroad with either a partner or a child aged under 18 or both), and only $19 \%$ with a partner or a child left in Latvia, while for the low-educated the figures were $54 \%$ with a partner or child living with them and $26 \%$ with close family remaining in Latvia (Fig. 3.10).

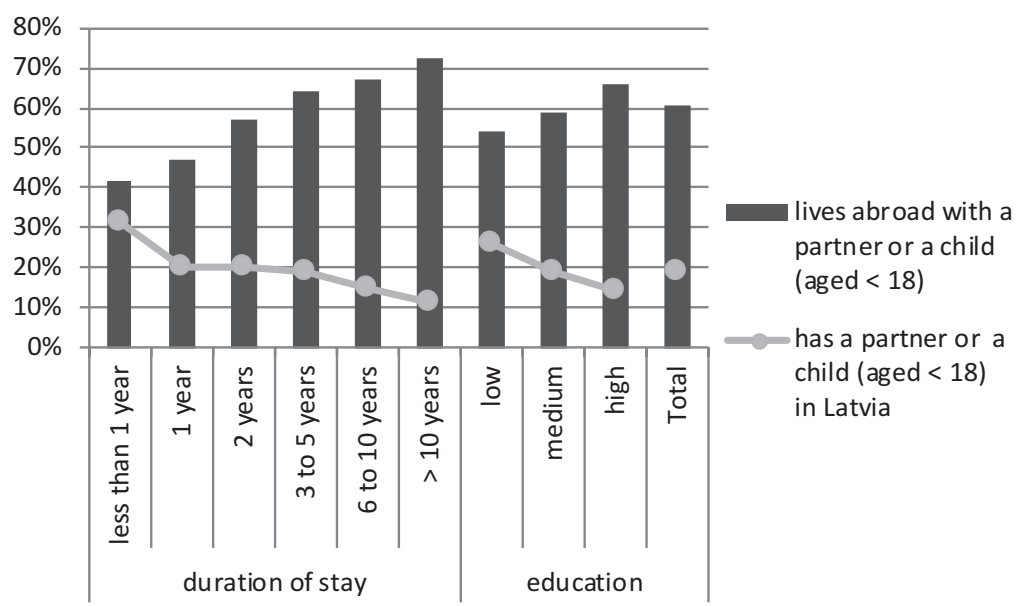

Fig. 3.10 Post-2000 emigrants' partners and children in Latvia and abroad, by duration of stay in the host country and completed education level, 2014. (Source: Calculation with The Emigrant Communities of Latvia survey data) 
How and why did the crisis change the profile of emigrants? The crisis increased joblessness particularly among those without higher education and even more among those without secondary education (Hazans 2012, Fig. 6.3, 2013, Table 4.5). On the other hand, the relative labour market position of ethnic minorities (especially non-citizens) deteriorated during the crisis (Hazans 2010, Fig. 9, 2013, Table 4.5; 2016a, Fig. 6). At the same time, the state language proficiency requirements in the private sector were tightened and became almost universal in terms of the occupations covered (Hazans 2010, p. 151, 2011a, p. 187). Finally, while Latvian non-citizens and residents with citizenship of Russia and other CIS countries were still not covered by the free mobility provisions, the share of this category among the working-age minority population declined - not least because during the postaccession period many had passed the exams and received Latvian citizenship in order to become eligible for the free mobility provisions. Hence, based on domestic economic factors alone, one should expect a significant increase in the proportions of the low-skilled and Russian-speakers among the crisis-period emigrants ${ }^{9}$.

While economic considerations do not suggest that the crisis should intensify the brain drain, such a hypothesis emerges from the dominant perception in Latvia of the crisis as systemic. This is because people who have invested in higher education are usually future-oriented and more concerned with lost perspective and disappointment in the quality of governance. The latter point is in line with the IMF (2016: Fig. 5) finding that in Central, Eastern and South-Eastern Europe, the quality of institutions has a stronger impact on the emigration of skilled workers than unskilled workers. Indeed, in early 2011, more than half the highly-educated potential emigrants reported only non-economic reasons for their plans to leave the country, while among the lower and medium-educated this proportion was below one-quarter and one-third (Hazans 2013, Fig. 4.13).

Evidence from The Emigrant Communities of Latvia survey conducted in 2014 confirms that during the crisis the importance of both economic and non-economic push factors, better social security abroad, as well as family-related factors sharply increased compared to the pre-crisis period (Hazans 2016a, Fig. 7) ${ }^{10}$. Moreover, family reasons apart, these changes were more pronounced among the high-educated and also persisted after the crisis (Fig. 3.11).

Figure 3.12 highlights three important messages. First, net emigration outflow from Latvia during the six crisis and post-crisis years (2009-2014) was much larger than during the nine pre-crisis years (2000-2008). Secondly, the largest increase in the number of emigrants is found among the highly-educated. Thirdly, the increase in the number of highly-educated emigrants was driven mainly by those who were not motivated by economic push factors. This provides empirical support to the hypothesis that the crisis intensified brain drain from Latvia and boosted the importance of non-economic reasons for emigration.

\footnotetext{
${ }^{9}$ See Hughes (2005) and Ivlevs (2013) for some theoretical considerations, and Hazans (2013, Table 4.8, 2016b) for empirical evidence on intentions.

${ }^{10} \mathrm{McCollum}$ et al. (2017) present similar findings (apart from family reasons) based on another, smaller survey.
} 


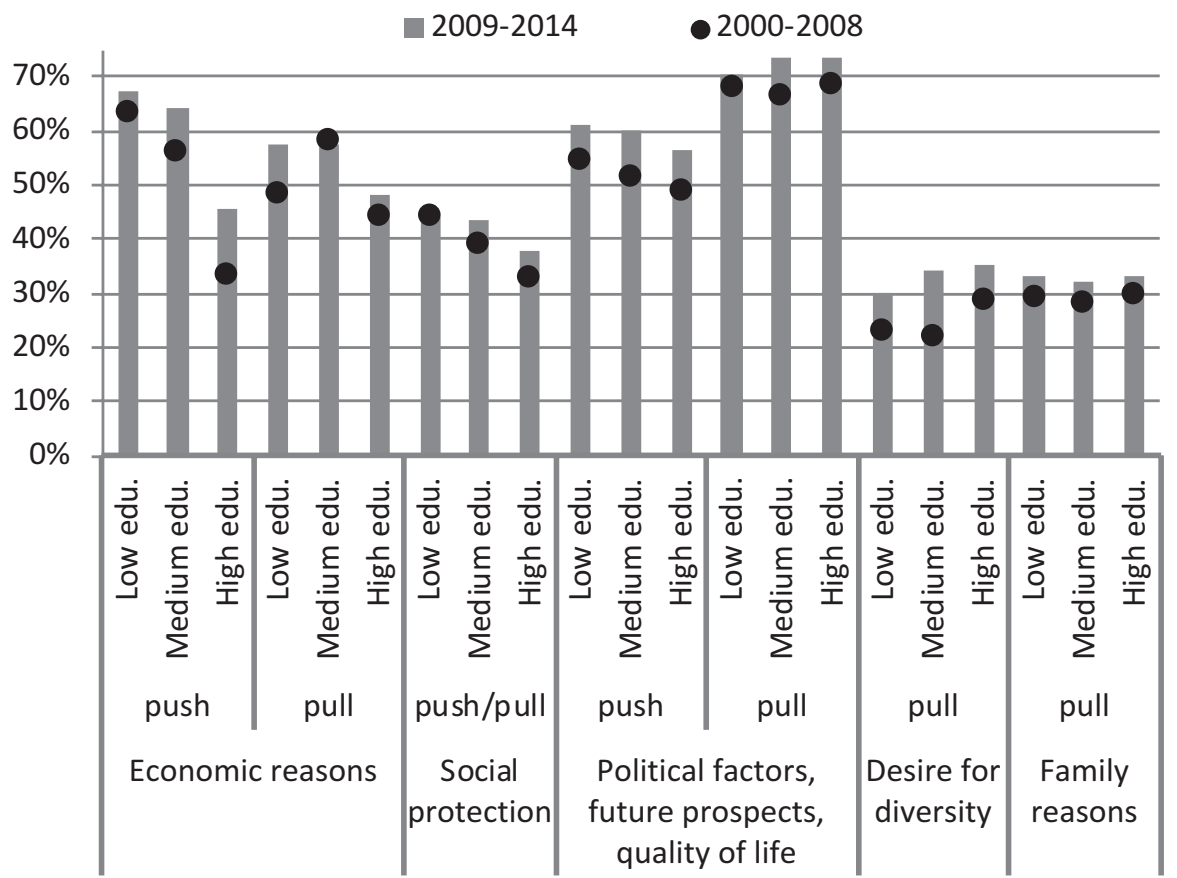

Fig. 3.11 Motivation for emigration, by education level and period of emigration. (Source: Calculation with The Emigrant Communities of Latvia survey data (Hazans 2018, Fig. 8). Note: Respondents could choose all relevant reasons from 17 given (the median number of reasons is 4 for the high-educated and 5 for others). See $\operatorname{OECD}$ (2016, Fig. 2.7) for a detailed list of reasons in each group)

Note that data in Fig. 3.12 also account for higher education completed after emigration; i.e. measuring the total brain drain rather than 'diploma' drain (see Hazans 2016a), but the results are qualitatively similar when the education level completed in Latvia is used.

\subsubsection{The Post-crisis Wave (2011-2016): Emigration as 'the New Normal'}

In the first 3 years after the Great Recession, despite an economic recovery, there have been no clear signs of a considerable slowdown in emigration from Latvia - it has remained well above the pre-crisis level (Table 3.2; Fig. 3.6). In 2014-2016, emigration outflows fell by roughly one-quarter but were still above the level of the last pre-crisis years 2007-2008 (Fig. 3.6). 


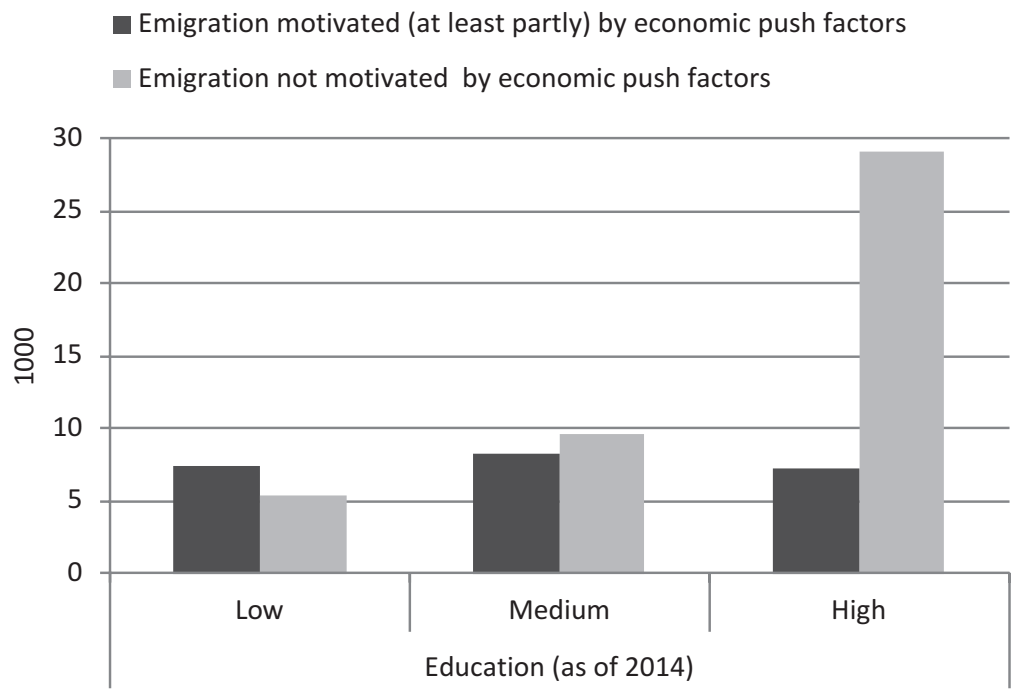

Fig. 3.12 Increase in the number of settled emigrants from Latvia between 2000 and 2008 and 2009-2014, by education level in 2014 and the presence of economic push factors as reasons for emigration. (Source: Hazans (2018, Fig. A6). Note: Economic push factors include financial difficulties, the inability to make ends meet and inability to find a job in Latvia. The results are qualitatively similar when the education level completed in Latvia is used)

By 2011, 82\% of Latvia's population aged 18-65 had some relative or friend with foreign work experience (Hazans 2011b, Box 2.25), while a recent survey put that figure at $91 \%$ among those aged 18-74 (LETA 2017). This suggests that work abroad has become an integral part of the Latvian national identity (Hazans 2013), and in the post-crisis period, emigration is 'the new normal' (Hazans 2016a). Powerful migration networks significantly reduce information and job search costs, as well as psychic and adaptation costs for potential emigrants, which explains the persistently high emigration potential. According to surveys, this was more than $20 \%$ of the population aged 18-64 in 2013-2015, but dropped to15\% in 2016 (Fig. 3.13). Migration flows are shaped by migrant networks, along with alreadyformed but not yet implemented intentions for emigration.

Paradoxically, growing vacancy rates and falling unemployment in Latvia (Hazans 2018) might contribute to these emigration intentions by reducing the risk for potential emigrants in case emigration appears to be working out unsuccessfully or their return is triggered by family reasons.

Pull factors have gained in importance among the drivers of emigration and while economic reasons for emigration remain widespread, non-economic ones are becoming increasingly important (Fig. 3.11; Hazans 2016a, Fig. 7; OECD 2016, Fig. 2.5). In terms of destinations, Germany, which opened its labour market for EU-10 workers in 2011, increased its share in outflows from Latvia (Fig. 3.6). This has had an impact on the composition of these migration flows, as Germany is more attractive than, say, the UK, for middle-aged skilled manual workers. 


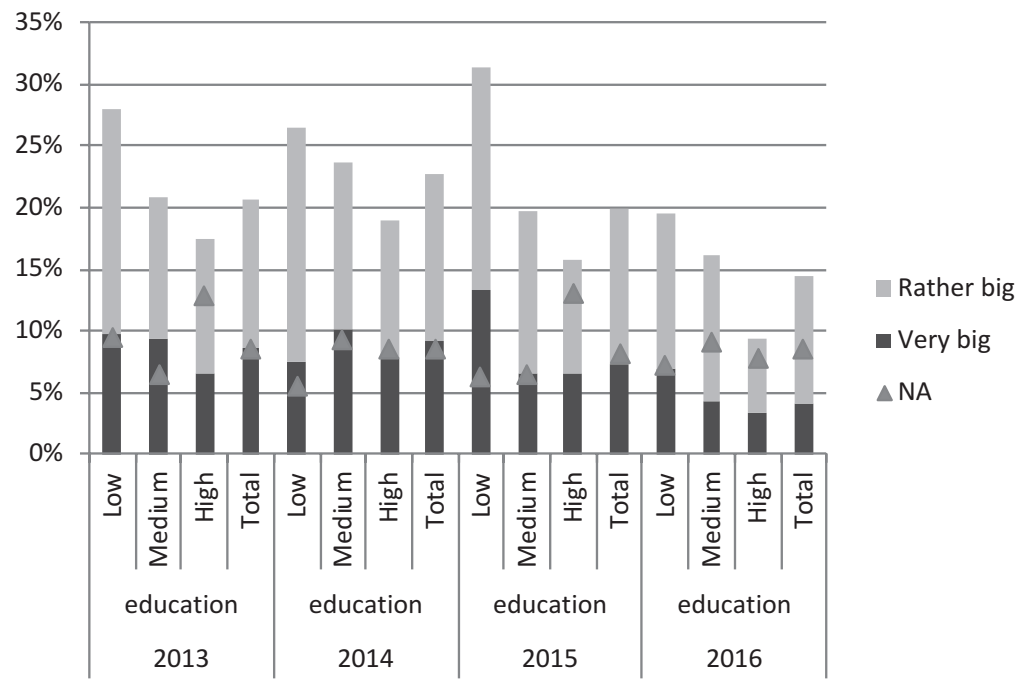

Fig. 3.13 Emigration intentions in Latvia, 2013-2016 (population aged 18-64), by completed education level. The survey question was: 'How big is the probability that in the near future you might move to work abroad'? (Source: Calculations with representative population survey data conducted by SKDS)

\subsection{The Evolution in Composition of the Four Waves of Emigrants}

\subsubsection{Ethnicity}

Figure 3.14 presents empirical evidence on the ethnic composition of the four recent waves of emigrants. ${ }^{11}$ As seen in Panel A, the share of minorities among the individuals working abroad but still considered household members at home is U-shaped, reaching its lowest point in 2006-2008, when the ethnic gaps in employment and unemployment were at their lowest values (Hazans 2016a, Fig. 6), and increasing during the crisis, when the relative labour market position of ethnic minorities deteriorated. The corresponding selectivity index ${ }^{12}$ (which accounts for the fact that the minority share in Latvia's population was declining over time and is smaller among the youth and the middle-agers than among the elderly) follows the same pattern, in line with expectations stated in Sects. 3.5.3 and 3.5.4.

\footnotetext{
${ }^{11}$ This section builds on the author's previous work (Hazans 2016a, 2018). On Russian-speaking emigrants from Latvia, see also Ivlevs (2013), Lulle and Jurkane-Hobein (2016).

${ }^{12}$ The selectivity index $S I=\ln \left(P_{\mathrm{M}} / P_{\mathrm{S}}\right)$, where $P_{\mathrm{M}}$ and $P_{\mathrm{S}}$ are shares of minorities (or any other group of interest) among movers and stayers. The $S I$ is positive if minorities are over-represented among movers (Hazans 2011b, 2016a).
} 


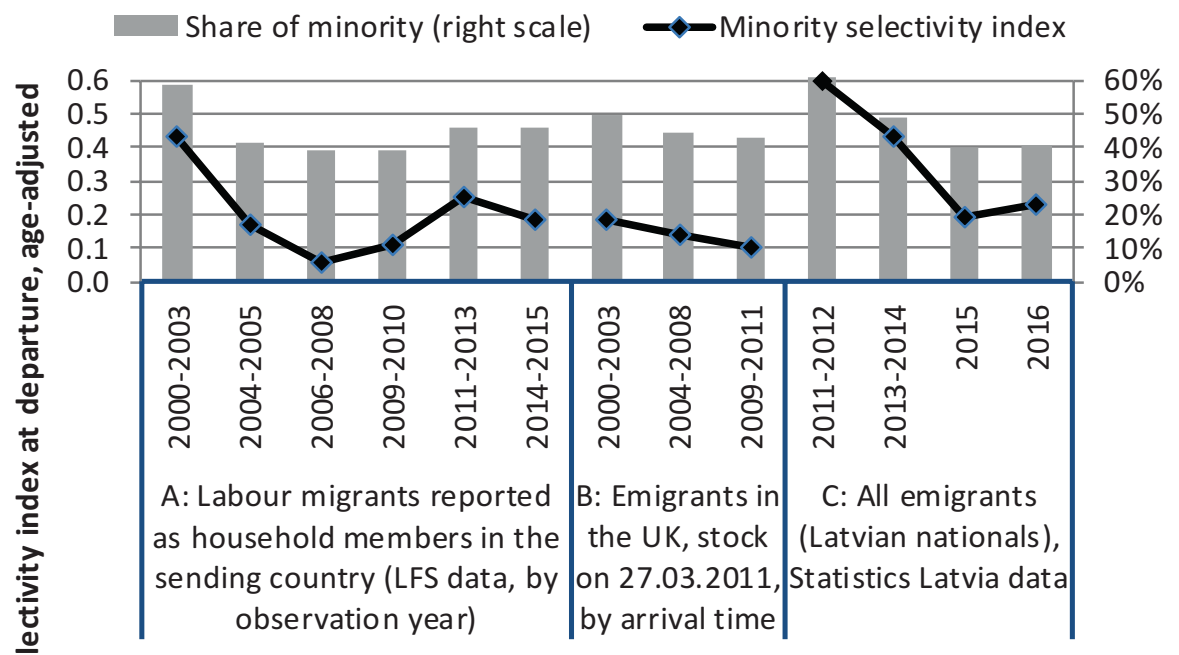

Fig. 3.14 Ethnic composition and selectivity of emigrants from Latvia, 2000-2016. (Source: Calculation with data of Latvian LFS, UK Population Census 2011 (ONS Tables CT0255, CT0333), and Central Statistical Bureau of Latvia (2017g). Note: In Panel B, the data cover only England and Wales. In panel C, data for years before 2011 are not available)

Russian speakers were over-represented among mobile workers still attached to their Latvian households in the whole period between 2000 and 2015, as indicated by the positive values of the selectivity index.

Panel B of Fig. 3.14 is based on the data of the UK Population Census 2011 and refers to Latvia-born residents of England and Wales who arrived in the UK in the period 2000-2011 (before the Census). For 2005-2011, these data (free from the restriction that the emigrants are still considered household members in Latvia) also suggest that the proportion of non-Latvians among emigrants is slightly above $40 \%$ (i.e. higher than among stayers) and supports our expectation that the proportion of ethnic minorities among post-accession emigrants was smaller than before. Panel B does not feature an increase in the minority selectivity index caused by the crisis; this might have to do with the nature of the Census data (recent crisis-driven migrants, especially the low-skilled, were less likely to take part in the Census).

Finally, Panel C covers only the post-crisis period and indicates that minorities were substantially over-represented among emigrants. This is in line with changes in language policy and the labour market position of minorities, as described in Sect. 3.5.4, as well as with intention-based evidence in Hazans (2013, Table 4.8, 2016b, pp. 8-10). 


\subsubsection{Education Level}

By early 2011, emigrants from Latvia who had lived in OECD countries for up to 10 years featured larger shares of the tertiary-educated than their age peers in Latvia, and this was especially pronounced among early post-crisis emigrants (Fig. 3.15). On the other hand, the low-educated were also somewhat over-represented among Latvian emigrants in European OECD countries. Emigrants in the main nonEuropean destinations appear to be much better educated; a finding consistent with the idea that a migration-friendly institutional environment in the EU lowers the human capital threshold for potential migrants.

Latvian mobile workers still considered household members back home appear to be less well-educated than settled emigrants, suggesting that highly-skilled emigrants are more likely to stay in their destination countries for prolonged periods or permanently. This finding emerges from a comparison of LFS-based data (Fig. 3.16) with the Census-based data in Fig. 3.15.

The selectivity indices in Fig. 3.16 compare mobile workers with Latvia's population aged 18-64 in the same period, thus measuring the effect on the working-age population.

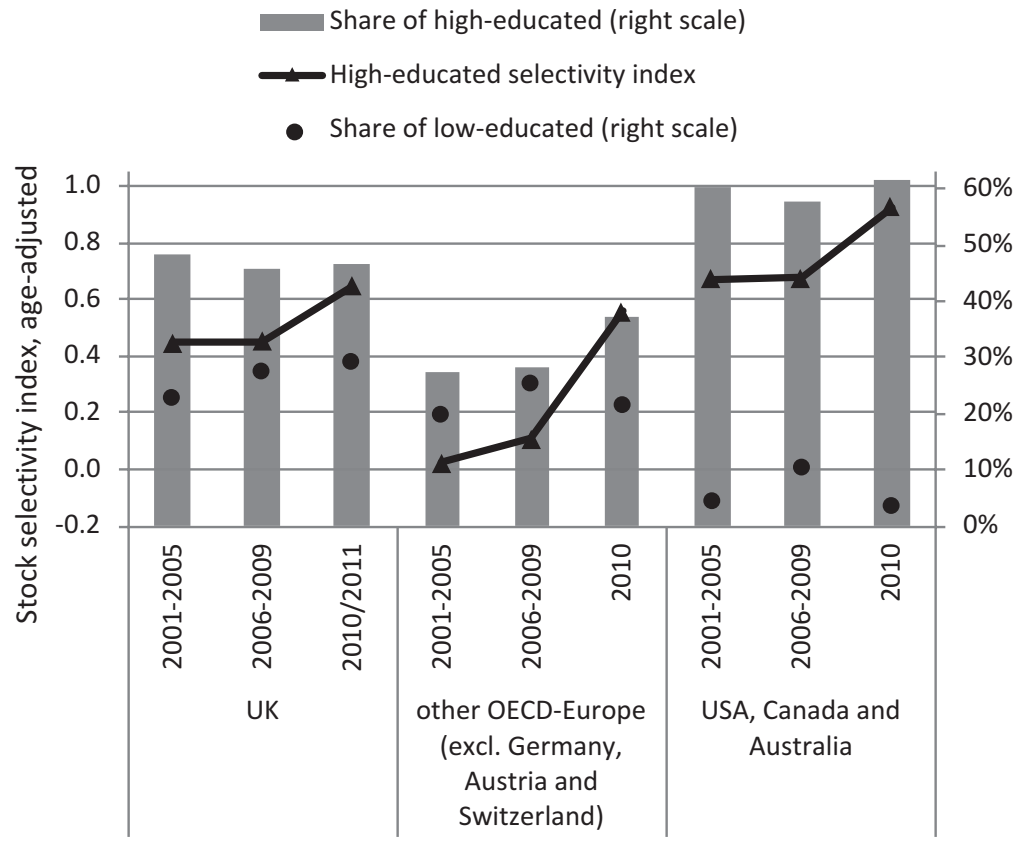

Fig. 3.15 Skill composition and selectivity of twenty-first century emigrants from Latvia. OECD countries, early 2011. (Sources: Calculation with data of OECD 2014 and Eurostat data Hazans 2018, Fig. 9) 

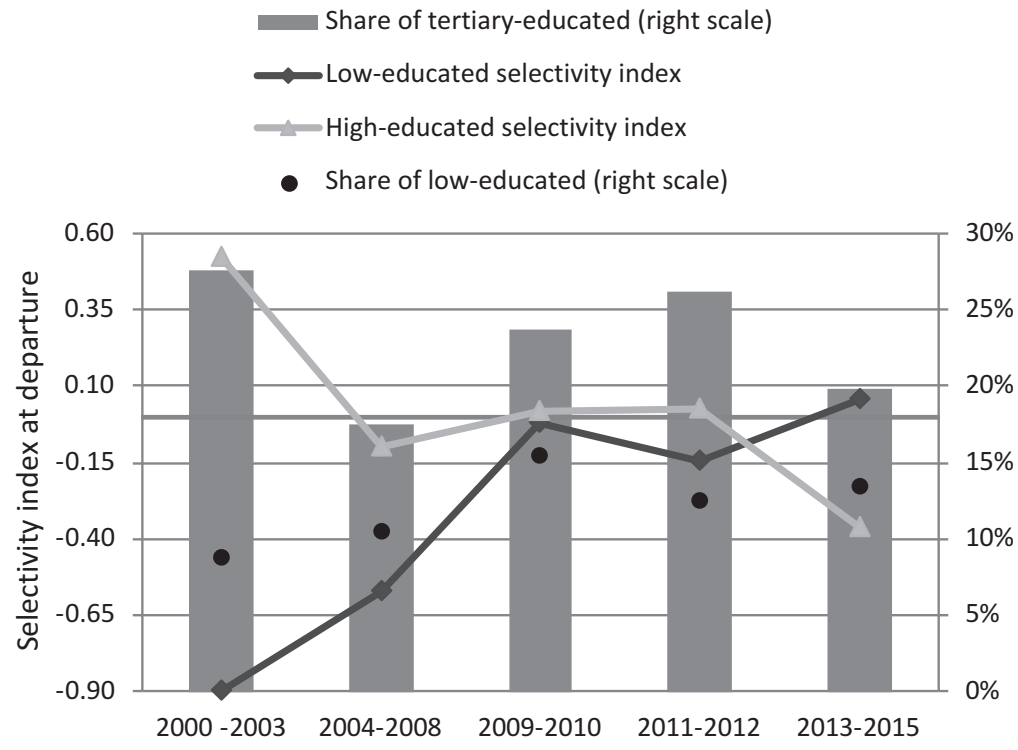

Fig. 3.16 Skill composition and selectivity of Latvian mobile workers reported as household members back home, 2000-2015. (Source: Calculations with the Latvian LFS data (builds on Hazans 2018, Fig. 10). Notes: The selectivity indexes compare mobile workers with Latvia's population aged $18-64$ in the same period)

University graduates were over-represented among pre-accession mobile workers. In line with the expectations outlined in Sect. 3.5.3, the share of the higheducated and the corresponding selectivity index drop in the post-accession period. The share and selectivity of the low-skilled increases - reflecting the effect of free mobility provisions which lowered the human capital threshold for moving - while there are also higher expected gains for the lower and medium-skilled).

During and after the crisis, the share and selectivity index of the high-educated among the mobile workers was above pre-crisis levels (consistent with findings from Fig. 3.15 for settled emigrants and in line with expectations in Sect. 3.5.4), but fell again in 2013-2015. The latter observation should be considered with care, because it might indicate either smaller outflows of the high-educated or a switch to full-family emigration (which is not observed in LFS data). The share (and selectivity index, not shown in Fig. 3.15) of the low-educated stayed above pre-crisis levels throughout 2009-2015, reflecting the fact that the low-skilled suffered more and for longer from recession-related joblessness. ${ }^{13}$

Data from The Emigrant Communities of Latvia survey confirm a substantial university diploma drain from Latvia to various EU/EFTA destinations during the whole period between 2000 and 2014 (Fig. 3.17). This increases over time, except

\footnotetext{
${ }^{13}$ McCollum et al. (2017) also find a higher share of the lower-skilled among post-crisis emigrants.
} 


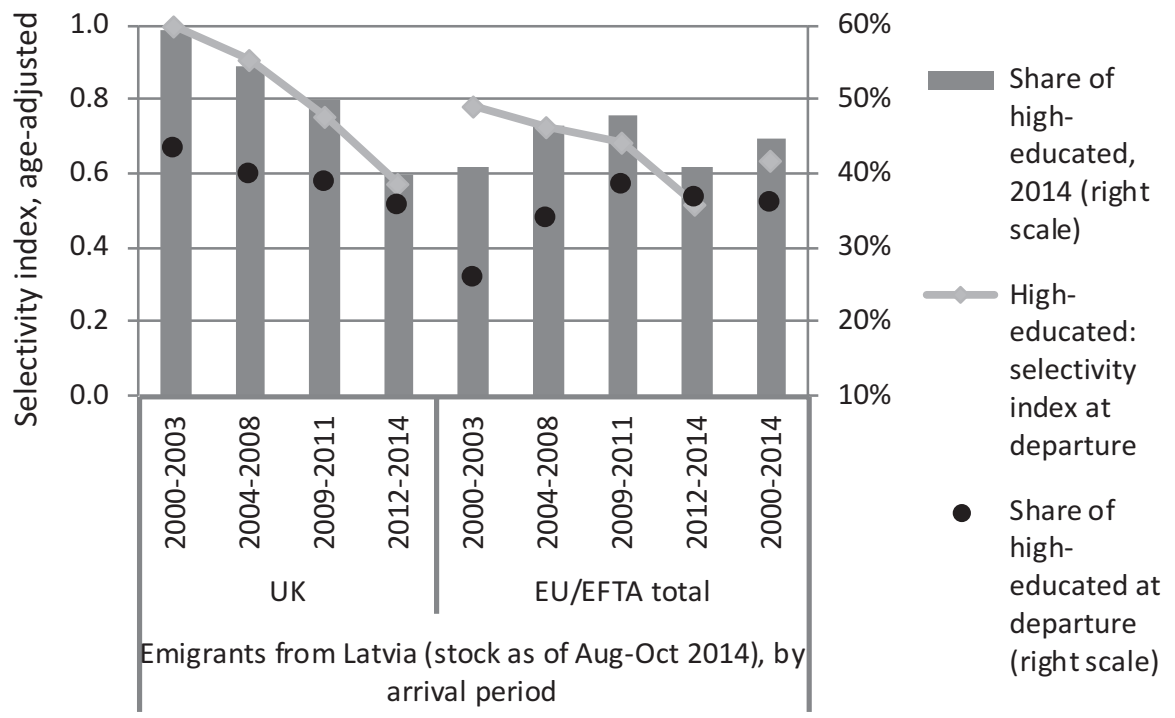

Fig. 3.17 Shares and selectivity of the high-educated among adult emigrants from Latvia, 20002014, by destination and arrival period. (Source: Calculation with The Emigrant Communities of Latvia survey data and Eurostat data (builds on Hazans 2018, Fig. 7). Note: The selectivity index at departure compares, for each destination and arrival period, the share of emigrants who left Latvia aged $15+$ with a completed tertiary education with the share of tertiary-educated stayers in that period, assuming the same age distribution as for those who moved from Latvia during that period)

for the most recent period. The shares of the high-educated among emigrants were well above those found in respective periods among stayers of the same age as emigrants, as indicated by the positive values of the age-adjusted selectivity index at departure (ranging between 0.51 and 0.78 for the total outflow to EU/EFTA).

Figure 3.17 also illustrates how the share of the tertiary-educated among emigrants further increased during their stay in the host countries, reaching, by 2014, $45 \%$ (on average across destinations and arrival periods).

Latvia's accession to the EU in 2004 has boosted the diploma drain in absolute terms, but in relative terms it became less intensive than before, as suggested by the falling selectivity index (Fig. 3.17). Moreover, for the UK, which was the main destination after accession, the share of the high-educated among post-accession emigrants surveyed in 2014 is lower than among their pre-accession counterparts. This is consistent with theoretical expectations (see Sect. 3.5.3) based on institutional and market factors: the free movement of labour lowered both migration costs and the human capital threshold.

Evidence from The Emigrant Communities of Latvia survey (shares of university graduates at departure found in Fig. 3.17, as well as the stock selectivity index presented in (Hazans 2018:Fig. 7) suggests that during the crisis, the diploma drain and brain drain from Latvia was more intensive than before, reflecting a rise in general 
disappointment and non-economic reasons for emigration among the high-educated and the future-oriented (see Hazans 2011b, 2012, 2013, 2016a, as well as Fig. 3.11 above). This trend also continued after the crisis, except for the UK.

\subsection{Conclusion}

This chapter presents a brief history of migration to and from Latvia and the evolution of its driving forces in the early twenty-first century. The empirical findings from a number of independent data sources are in line with expectations based on a theoretical analysis of the economic, social and institutional context of four emigration waves and the underlying migration systems.

In the twentieth century, Latvia experienced two world wars and three occupations. Thousands of economic migrants, refugees and displaced people moved from Latvia in some periods and to Latvia in others. Net annual migration rates featured large swings from $-7.5 \%$ to $-2.9 \%$ during the two world wars to $2.8 \%$ and $6.9 \%$ in the post-war periods.

Migration to Latvia from other parts of the Soviet Union continued at high (although decreasing) rates until 1989. Key elements which kept this migration system going included: (i) centralised decision-making on the allocation of resources, including the labour force; (ii) the Russian language as the Soviet Union's lingua franca (iii) a higher standard of living in Latvia than almost elsewhere in the Soviet Union. As the result, by 1989 the share of ethnic Latvians in Latvia's population fell to just above one-half.

However, the last decade of the twentieth century has seen a massive outflow of the Russian-speaking population from restored independent Latvia to Russia and other CIS countries. On the Latvian side, the rise of this migration system was triggered by dramatic changes in political regime, prevailing historical narrative, language environment, structure of labour demand, and, for many, loss of citizenship. Key elements for the post-war immigrants to Latvia included strong family, social and professional networks in Russia and other CIS countries, as well as relatively easy access to citizenship there.

By 2000, due to outflow of the Russian-speakers and - though much smaller in scale - the return of ethnic Latvians from the West and Russia, the population share of ethnic Latvians had reached almost 58\%.

The 1990s also saw pioneer emigration to the West. The migration system emerging at this time was a hybrid one, relying either on support from the rich social infrastructure created in the West by the post-war Latvian refugees or from less formal social networks among Russian-speaking emigrants from the Soviet Union. A third factor was the ability of the pioneers to find their way themselves. By the end of the twentieth century, the post-Soviet Latvian diaspora in OECD countries accounted for around 21,000 people, implying net migration of less than $1 \%$ of the population in 10 years. 
The pre-accession emigration wave (2000-2003) featured substantial positive selectivity on human capital and other personal characteristics, an over-representation of Russian-speakers and a high degree of geographical diversification. During this wave, the net outflow of Latvian nationals was $1.4 \%$ of the initial population.

The post-accession wave (2004-2008) was shaped by:

- The gradual implementation of the free movement of labour within the EU;

- The high and growing demand for migrant labour in the EU15;

- Advances in information and communication technologies;

- Falling prices for international telecommunication and air travel and

- The availability of free information via EURES consultants and the European Mobility Portal.

All these factors substantially lowered the monetary and non-monetary costs of labour migration and the human capital threshold, as well as the related uncertainty, such as the risk of failed migration. This triggered a sharp and - to a large extent persistent increase in emigration rates, which further lowered migration costs via the expanding migrant networks.

Post-accession emigration was mainly driven by pull factors, while the role of push factors declined during the period especially for ethnic minorities, due to strong economic growth and developing labour shortages in Latvia. On the other hand, a substantial part of the minority population - i.e., those without Latvian citizenship - was not covered by the free movement of labour within the EU.

Summing up, it can be seen that in comparison with the pre-accession period, the post-accession emigrants from Latvia were, as a group, less well-educated and featured a significantly lower proportion of ethnic minorities, especially non-citizens. The post-accession migration was, to a large extent, short-term and/or cyclical, yet many emigrants have chosen to settle in their destination countries, and the Latvian diaspora abroad grew steadily. The net outflow of nationals from Latvia in the five post-accession years accounts for 3.2\% of its population at the beginning of 2000 .

During the years of the Great Recession (2009-2010), both economic and noneconomic push factors gained importance among the reasons for emigration. Factors such as high and persistent unemployment, a weak social security system and lost perspectives converged to make emigration a real option in the minds of Latvia's residents, even for those who had not considered it before. The expected economic gains from emigration also increased in comparison to the pre-crisis period.

The post-accession migration system has been substantially transformed and expanded. The crisis triggered a strong shift from the temporary emigration of breadwinners towards the long-term or permanent emigration of entire families. Both gross and net emigration rates have increased sharply. The annual rate of net migration during the crisis and the first two post-crisis years (2009-2012) was more than twice as high as during the post-accession wave. The net outflow of Latvia's nationals in 2009-2012 accounts for 5.3\% of country's population at the beginning of 2000 .

The crisis has led to the deterioration of relative labour market positions of the low-educated and of the Russian-speakers; as a result, the proportions of these 
groups among the emigrants has increased significantly. On the other hand, the crisis intensified the 'brain drain' from Latvia and boosted the importance of noneconomic reasons for emigration, especially among the high-educated.

In the post-crisis years, despite economic growth in Latvia, working abroad has become an integral part of the Latvian national identity. Emigration, actual or planned, is 'the new normal'. While the economic reasons for emigration remain widespread, non-economic ones have become increasingly important. Migration flows are shaped by migrant networks, along with already-formed but not yet implemented emigration intentions. Minorities and university graduates remain overrepresented among emigrants. Emigration potential is persistently high, and only a small percentage of the emigrants return or plan to return (Hazans 2015b, p.10, 2015d, 2016a, p.335). Moreover, one in four returnees plans to move abroad again (Hazans 2016c, Table 3, 2017b, p. 40).

In conclusion, despite the passing of the economic crisis in Latvia, the impact of the normalising of emigration has profound consequences for the future. The brain drain of university graduates continues and few of the emigrants have plans to come back. What is even more worrying is that of those emigrants who have returned to Latvia after the crisis, one in four is planning to leave to work abroad again.

\section{References}

Bakewell, O. (2014). Relaunching migration systems. Migration Studies, 2(3), 300-318.

Bakewell, O., de Haas, B., \& Kubal, A. (2011). Migration systems, pioneers, and the role of agency. IMI Working Papers Series No. 48. Oxford: International Migration Institute. https:// ora.ox.ac.uk/objects/uuid:c5b723c0-4de2-44e1-afd7-6f346ee0df0d/download_file?file_ format=pdf \&safe_filename $=\mathrm{WP} 48 \% 2 \mathrm{BMigration} \% 2 \mathrm{~B}$ systems $\% 2 \mathrm{~B}$ pioneers $\% 2 \mathrm{~B}$ and $\% 2 \mathrm{~B}$ the \%2Brole\%2Bof\%2Bagency.pdf\&type_of_work=Working+paper. Accessed 2 Dec 2018.

Borjas, G. J. (1987). Self-selection and the earnings of immigrants. American Economic Review, 77(4), 531-553.

Borjas, G. J. (1999). Immigration and welfare magnets. Journal of Labor Economics, 17(4), 607-637.

Carrington, W. J., Detragiache, E., \& Vishwanath, T. (1996). Migration with endogenous moving costs. American Economic Review, 86(4), 909-930.

Central Statistical Bureau of Latvia. (2016a). Natural population change, 1920-1938. http://www. csb.gov.lv/en/statistikas-temas/px_tabulas/natural-population-change-1920-1938-44729.html. Accessed 17 Dec 2017.

Central Statistical Bureau of Latvia. (2016b). Population - Number and density. http://www.csb. gov.lv/en/statistikas-temas/population-number-and-density-33079.html. Accessed 15 Dec 2016.

Central Statistical Bureau of Latvia. (2016c). Historical Census publications. 2nd Latvia's Population census, 1925. Language Skills. http://www.csb.gov.lv/sites/default/files/dati/ TSK_1929_04_05.pdf. Accessed 17 Dec 2017.

Central Statistical Bureau of Latvia. (2017a). ISG03. Changes of resident population by factor.

Central Statistical Bureau of Latvia. (2017b). Census of Latvia from 1925 to 2011. http://www. csb.gov.lv/en/statistikas-temas/census-latvia-1925-2011-39110.html. Accessed 15 Dec 2016.

Central Statistical Bureau of Latvia. (2017c). IBG01. Long-term migration. 
Central Statistical Bureau of Latvia. (2017d). IBG02. International long-term migration by country group.

Central Statistical Bureau of Latvia. (2017e). ISG07. Resident population by ethnicity at the beginning of the year.

Central Statistical Bureau of Latvia. (2017f). ISVG02. Natural increase by ethnicity.

Central Statistical Bureau of Latvia. (2017g). IBG041, IBG043. International long-term migration by ethnicity and citizenship. https://data1.csb.gov.lv/pxweb/en/iedz/iedz__migr/?tablelist=true \&rxid=84263452-9db0-4a60-ab2f-b4465d46f4d7. Accessed 2 Dec 2018.

de Haas, H. (2010). The internal dynamics of migration processes: A theoretical inquiry. Journal of Ethnic and Migration Studies, 36, 1587-1617.

European Commission. (2011). Labor market developments in Europe, 2011. http://ec.europa.eu/ economy_finance/publications/publication_summary-20110809_en.htm. Accessed 28 Nov 2015.

Fries-Tersch, E., Tugran, T., \& Bradley, H. (2017). 2016 Annual report on intra-EU labour mobility (2nd ed.). Brussels: European Commission.

Hazans, M. (2010). Ethnic minorities in Latvian labour market, 1997-2009: Outcomes, integration drivers and barriers. In N. Muižnieks (Ed.), How integrated is Latvian Society? An audit of achievements, failures and challenges (pp. 125-158). Riga: University of Latvia Press.

Hazans, M. (2011a). Labor market integration of ethnic minorities in Latvia. In M. Kahanec \& K. F. Zimmermann (Eds.), Ethnic diversity in European labor markets: Challenges and solutions (pp. 163-197). Northampton: Edward Elgar.

Hazans, M. (2011b). The changing face of Latvian emigration, 2000-2010. In B. Zepa \& E. Kḷave (Eds.), Latvia. Human development report 2010/2011: National identity, mobility and capability (pp. 77-101). Riga: University of Latvia Press.

Hazans, M. (2012). Selectivity of migrants from Baltic countries before and after enlargement and responses to the crisis. In B. Galgóczi, J. Leschke, \& A. Watt (Eds.), Intra-EU migration in troubled times: Skills mismatch, return migration and policy responses (pp. 169-207). Farnham: Ashgate.

Hazans, M. (2013). Emigration from Latvia: Recent trends and economic impact. In OECD (Ed.), Coping with emigration in Baltic and East European countries (pp. 65-110). Paris: OECD Publishing.

Hazans, M. (2014). Emigration intentions and fertility potential in Latvia. Presentation at the conference Labour Mobility and Transnationalism in the Nordic-Baltic Region, Tallinn, Estonia. https://doi.org/10.13140/RG.2.2.34485.17121.

Hazans, M. (2015a). Poland and the Baltics: The nature of the four emigration waves over 2000-2013. Presentation at The World Bank-European Commission Joint Seminar on Active Aging, Brussels, Belgium. https://doi.org/10.13140/RG.2.2.32178.30408.

Hazans, M. (2015b). Return migration intentions to Latvia, based on recent survey of emigrants. Presentation at the conference Migration in the Nordic - Baltic Region. New Trends of Labour Migration - Ready for the Changes? Tallinn, Estonia. https://doi.org/10.13140/ RG.2.2.35284.71042. https://www.researchgate.net/publication/319242208_Return_ Migration_Intentions_to_Latvia_Based_on_Recent_Survey_of_Emigrants. Accessed 17 Dec 2016.

Hazans, M. (2015c). Return intention of post-2000 emigrants from Latvia. Background paper for OECD (2016).

Hazans, М. (2015d). Для многих отъезд из Латвии - история успеха [For many, emigration from Latvia is a success story]. Открытый город, 5(62), 52-57. http://www.freecity.lv/obshestvo/23637. Accessed 3 May 2016.

Hazans, M. (2016a). Migration experience of the Baltic Countries in the context of economic crisis. In M. Kahanec \& K. F. Zimmermann (Eds.), Labor migration, EU enlargement, and the Great Recession (pp. 297-344). Berlin: Springer.

Hazans, M. (2016b). Emigration intentions in post-crisis Latvia. Presentation at the conference New Challenges of Economic and Business Development-2016, Riga, Latvia. https://doi. org/10.13140/RG.2.2.12187.36648. 
Hazans, M. (2016c). Atgriešanās Latvijā. Remigrantu aptaujas rezultāti [Returning to Latvia: Evidence from survey of return migrants]. http://www.diaspora.lu.lv/fileadmin/user_upload/ lu_portal/projekti/diaspora/petijumi/Atgriesanas_Latvija_-_petijuma_zinojums.pdf. Accessed 18 Dec 2017.

Hazans, M. (2017a). Labour mobility: Challenge or chance? Evidence from the Baltics and Poland in the 21 st century. Presentation at the Baltic Sea Labour Forum Round Table, Berlin, Germany. https://doi.org/10.13140/RG.2.2.20156.54409.

Hazans, М. (2017b). Чем родина встречает возвраменцев [What has the homeland to offer to returnees?]. Открытый город, 5(86), 36-40. http://www.freecity.lv/arhiv/133/. Accessed 29 Nov 2017.

Hazans, M. (2018). Labour market policy thematic review 2018: An in-depth analysis of the emigration of skilled labour. Latvia. Brussels: European Commission, Directorate-General for Employment, Social Affairs and Inclusion. European Centre of Expertise (ECE).

Hazans, M., \& Philips, K. (2010). The post-enlargement migration experience in the Baltic labor markets. In M. Kahanec \& K. F. Zimmermann (Eds.), EU labor markets after post-enlargement migration (pp. 255-304). Berlin: Springer.

Hughes, J. (2005). 'Exit' in deeply divided societies: Regimes of discrimination in Estonia and Latvia and the potential for Russophone migration. Journal of Common Market Studies, 43(4), 739-762.

IMF. (2016). Emigration and its economic impact on Eastern Europe. IMF staff discussion note. https://www.imf.org/external/pubs/ft/sdn/2016/sdn1607.pdf. Accessed 16 Nov 2017.

Ivlevs, A. (2013). Minorities on the move? Assessing post-enlargement emigration intentions of Latvia's Russian speaking minority. The Annals of Regional Science, 51(1), 33-52.

Kahanec, M., Pytlikova, M., \& Zimmermann, K. F. (2016). The free movement of workers in an enlarged European Union: Institutional underpinnings of economic adjustment. In M. Kahanec \& K. F. Zimmermann (Eds.), Labor migration, EU enlargement, and the Great Recession (pp. 1-34). Berlin: Springer.

LETA. (2017). Galvenie iemesli iedzīvotāju emigrācijai-zems atalgojums, nespēja atrast darbu, in Latvian [Main reasons for emigration - low earnings and inability to find a job]. http://nra. lv/latvija/221719-galvenie-iemesli-iedzivotaju-emigracijai-zems-atalgojums-nespeja-atrastdarbu.htm. Accessed 1 Dec 2017.

Lulle, A. (2018). 'I no longer believe in the British 'word of honour': Young migrants reflect on Brexit. http://blogs.lse.ac.uk/brexit/2018/03/28/i-no-longer-believe-in-the-british-wordof-honour-young-migrants-reflect-on-brexit/. Accessed 30 Nov 2018.

Lulle, A., \& Jurkane-Hobein, I. (2016). Strangers within? Russian-speakers' migration from Latvia to London: A study in power geometry and intersectionality. Journal of Ethnic and Migration Studies, 43(4), 596-612. https://doi.org/10.1080/1369183X.2016.1249054.

Lulle, A., Moroşanu, L., \& King, R. (2018). And then came Brexit: Experiences and future plans of young EU migrants in the London region. Population, Space and Place, 24, e2122. https:// doi.org/10.1002/psp.2122.

Mabogunje, A. L. (1970). Systems approach to a theory of rural-urban migration. Geographical Analysis, 2, 1-18.

McCollum, D., Apsite-Berina, E., Berzins, M., \& Krisjane, Z. (2017). Overcoming the crisis: The changing profile and trajectories of Latvian migrants. Journal of Ethnic and Migration Studies, 43(99), 1508-1525. https://doi.org/10.1080/1369183X.2016.1232161.

Muižnieks, N. (2006). Government policy and the Russian minority. In N. Muižnieks (Ed.), Latvian - Russian relations: Domestic and international dimensions (pp. 11-21). Riga: University of Latvia Press.

National History Museum of Latvia. (2016). Latvians abroad 1944-1990. http://lnvm.lv/ en/? $\mathrm{p}=1425$. Accessed 30 Nov 2018.

OECD (2008). Database on Immigrants in OECD countries. Immigrants by duration of stay. https://doi.org/10.1787/data-00342-en. Accessed 2 Dec 2018.

OECD. (2012). Connecting with emigrants. A global profile of diasporas. Paris: OECD Publishing. https://doi.org/10.1787/9789264177949-en. 
OECD (2014). Database on immigrants in OECD countries (DIOC) 2010/11. https://doi. org/10.1787/data-00342-en. Accessed 2 Dec 2018.

OECD. (2016). OECD reviews of labour market and social policies: Latvia 2016. Paris: OECD Publishing. https://doi.org/10.1787/9789264250505-en. Accessed 23 Nov 2017.

OECD. (2017). International migration database. https://stats.oecd.org/Index. aspx ?DataSetCode=MIG. Accessed 30 Nov 2018.

Sjaastad, L. A. (1962). The costs and returns of human migration. Journal of Political Economy, 70(5), 80-93.

Stark, O., \& Bloom, D. E. (1985). The new economics of labor migration. American Economic Review, 75(2), 173-178.

Zelče, V. (2011). Major flows of migration: Early 19th century to 1991. In B. Zepa \& E. Kḷave (Eds.), Latvia. Human development report 2010/2011: National identity, mobility and capability (pp. 53-69). Riga: University of Latvia Press.

Open Access This chapter is licensed under the terms of the Creative Commons Attribution 4.0 International License (http://creativecommons.org/licenses/by/4.0/), which permits use, sharing, adaptation, distribution and reproduction in any medium or format, as long as you give appropriate credit to the original author(s) and the source, provide a link to the Creative Commons licence and indicate if changes were made.

The images or other third party material in this chapter are included in the chapter's Creative Commons licence, unless indicated otherwise in a credit line to the material. If material is not included in the chapter's Creative Commons licence and your intended use is not permitted by statutory regulation or exceeds the permitted use, you will need to obtain permission directly from the copyright holder. 